\title{
Low-temperature steam reforming of methanol to produce hydrogen over various metal-doped molybdenum carbide catalysts
}

\author{
Yufei Ma ${ }^{\mathrm{a}}$, Guoqing Guan ${ }^{\mathrm{a}, \mathrm{b} *}$, Chuan Shic*, Aimin Zhuc ${ }^{\mathrm{c}}$, Xiaogang $\mathrm{Hao}^{\mathrm{d}}$, \\ Zhongde Wang ${ }^{\mathrm{d}}$, Katsuki Kusakabe ${ }^{\mathrm{e}}$, Abuliti Abudula ${ }^{\mathrm{a}, \mathrm{b} *}$ \\ ${ }^{a}$ Graduate School of Science and Technology, Hirosaki University, 3 Bunkyo-cho, \\ Hirosaki, Aomori 036-8561, Japan \\ ${ }^{b}$ North Japan Research Institute for Sustainable Energy, Hirosaki University, 2-1-3 \\ Matsubara, Aomori 030-0813, Japan \\ 'Laboratory of Plasma Physical Chemistry, Dalian University of Technology, No.2 \\ Linggong Road, Ganjingzi District, Dalian City, Liaoning 116024, P. R. China \\ ${ }^{d}$ Department of Chemical Engineering, Taiyuan University of Technology, Taiyuan \\ 030024, China \\ ${ }^{e}$ Department of Nanoscience, Sojo University, 4-22-1 Ikeda, Nishi-ku, Kumamoto \\ 860-0082, Japan
}

Corresponding authors: Tel.: +81-17-762-7756; fax:+81-17-735-5411.

E-mails: guan@cc.hirosaki-u.ac.jp(G.Guan); $\quad$ chuanshi@dlut.edu.cn $\quad$ (C.Shi); abuliti@cc.hirosaki-u.ac.jp (A.Abudula)

(C) 2013. This manuscript version is made available under the Elsevier user license http://www.elsevier.com/open-access/userlicense/1.0/ 


\begin{abstract}
Various transition metals $(\mathrm{M}=\mathrm{Pt}, \mathrm{Fe}, \mathrm{Co}$, and $\mathrm{Ni})$ were selected to support on molybdenum carbides by in-situ carburization metal-doped molybdenum oxide $\left(\mathrm{M}-\mathrm{MoO}_{\mathrm{x}}\right)$ via temperature-programmed reaction $(\mathrm{TPR})$ with a final temperature of $700{ }^{\circ} \mathrm{C}$ in a reaction gas mixture of $20 \% \mathrm{CH}_{4} / \mathrm{H}_{2}$. XRD analysis results indicated that $\beta$-Mo2 $\mathrm{C}$ phase was formed in the case of $\mathrm{Fe}, \mathrm{Co}$, or Ni doping while $\alpha-\mathrm{Mo}_{2} \mathrm{C}$ phase was appeared with the $\beta-\mathrm{MoC}_{1-\mathrm{x}}$ phase in the case of Pt doping. With the increase in $\mathrm{Pt}$ doping amount, more $\alpha-\mathrm{MoC}_{1-\mathrm{x}}$ phase was produced. As-prepared metal doped molybdenum carbides were investigated as alternative catalysts for the steam reforming of methanol. Comparing with the undoped molybdenum carbide such as $\beta-\mathrm{Mo}_{2} \mathrm{C}$, metal-doped one showed higher methanol conversion and hydrogen yield. It is found that Pt doped molybdenum carbide had the highest catalytic activity and selectivity among the prepared catalysts and methanol conversion reached $100 \%$ even at a temperature as low as $200{ }^{\circ} \mathrm{C}$, and remained a long-time stability with a stable methanol conversion.
\end{abstract}

Keywords: Steam reforming of methanol; Molybdenum carbide; TPR method; Transition metal; Hydrogen production. 


\section{Introduction}

In order to solve environmental problems, development of clean energy technology is becoming more and more important from now. Hydrogen is considered one of ideal and clean energy carriers. However, since it is difficult to store compressed hydrogen safely and economically, production of hydrogen using on-board reformers by the steam reforming of hydrogen carrier is required. Among the different liquid hydrogen carriers available, methanol has the greatest potential when comparing with other hydrocarbon fuels because it has many advantages: it is a liquid fuel at ambient condition with a low activation temperature, a high hydrogen-to-carbon ratio, but coke (without $\mathrm{C}-\mathrm{C}$ bond) and sulfur free (no sulfur) [1-3]. Hydrogen can be produced from methanol by steam reforming, auto-thermal reforming, partial oxidation or even decomposition ways. Among these methods, the steam reforming of methanol (SRM) is considered the best way due to its high hydrogen yield. The SRM reaction can be expressed as:

$$
\mathrm{CH}_{3} \mathrm{OH}+\mathrm{H}_{2} \mathrm{O} \leftrightarrow \mathrm{CO}_{2}+3 \mathrm{H}_{2} \quad \Delta \mathrm{H}_{298 \mathrm{~K}}^{\circ}=49.3 \mathrm{~kJ} / \mathrm{mol}
$$

In the case of using stoichiometric feed, only $\mathrm{H}_{2}$ and $\mathrm{CO}_{2}$ will be produced from the steam reforming of methanol theoretically. However, other gases such as methane and carbon monoxide are usually produced together with $\mathrm{H}_{2}$ and $\mathrm{CO}_{2}$ in the product stream, relying on the types of catalysts and the reaction conditions due to the following reactions [4-6]. 


$$
\begin{aligned}
& \mathrm{CH}_{3} \mathrm{OH} \leftrightarrow \mathrm{CO}+2 \mathrm{H}_{2} \quad \Delta \mathrm{H}_{298 \mathrm{~K}}^{\circ}=91 \mathrm{~kJ} / \mathrm{mol} \\
& \mathrm{CO}+\mathrm{H}_{2} \mathrm{O} \leftrightarrow \mathrm{H}_{2}+\mathrm{CO}_{2} \quad \Delta \mathrm{H}_{298 \mathrm{~K}}^{\circ}=-41 \mathrm{~kJ} / \mathrm{mol} \\
& \mathrm{CO}+3 \mathrm{H}_{2} \leftrightarrow \mathrm{CH}_{4}+\mathrm{H}_{2} \mathrm{O} \quad \Delta \mathrm{H}_{298 \mathrm{~K}}^{\circ}=-206 \mathrm{~kJ} / \mathrm{m}
\end{aligned}
$$

Various catalysts have been developed for SRM reaction. $\mathrm{Cu}$ - and $\mathrm{Pd}-$ based catalysts are generally used because of their low CO production [4]. It is found that addition of $\mathrm{Zn}$ into the $\mathrm{Cu}$-based catalyst can improve the $\mathrm{Cu}$ dispersion[5]. However, $\mathrm{Cu}$-based catalysts have poor thermal stability when the reaction temperatures are over $300{ }^{\circ} \mathrm{C}$ due to the sintering of $\mathrm{Cu}$, and they also are easily deactivated by $\mathrm{H}_{2} \mathrm{~S}$ contaminates and chloride in the reactant stream[6, 7]. Noble metal based SRM catalysts such as $\mathrm{Pd} / \mathrm{CeO}_{2}, \mathrm{Pd} / \mathrm{ZnO}, \mathrm{Pd} / \mathrm{Ga}_{2} \mathrm{O}_{3}, \mathrm{Pd} / \mathrm{SBA}-15, \mathrm{Au} / \mathrm{Ce}_{1-\mathrm{x}} \mathrm{Zr}_{\mathrm{x}} \mathrm{O}_{2}, \mathrm{Au} / \mathrm{CeO}_{2}$, and $\mathrm{Pd} / \mathrm{Ga}_{2} \mathrm{O}_{3}$ have also widely investigated and showed high activities at a temperature between $200-400{ }^{\circ} \mathrm{C}[8-14]$. Recently, transition metal carbides such as tungsten carbide and molybdenum carbide have been attracted much attention because they show catalytic activities similar to those of noble metals in various reactions such as hydrogenation reactions, hydrocarbon isomerization, and methane and alcohol reforming [15-18]. Széchenyi and Solymosi prepared $\mathrm{Mo}_{2} \mathrm{C}$ by the carburization of $\mathrm{MoO}_{3}$ with $\mathrm{C}_{2} \mathrm{H}_{6} / \mathrm{H}_{2}$ mixture and found that it is an effective catalyst for the decomposition of ethanol and methanol with a high thermal stability[19]. When $\mathrm{Mo}_{2} \mathrm{C}$ was supported on carbon Norit, carbon nanotube, $\mathrm{ZrO}_{2}$ and $\mathrm{Al}_{2} \mathrm{O}_{3}$, a higher catalytic activity than an unsupported catalyst was identified [1, 20-22]. Furthermore, when carbides are served as supports, they could stabilize the formation of small, flat metal 
particles, leading to unique catalytic properties from the synergistic interaction of admetal particles and carbide substrates[23]. For instances, Lewandowski et al. dispersed $\mathrm{Pt}$ on the molybdenum carbide for simultaneous hydrodenitrogenation and hydrodesulfurization and found that the catalytic activitiy and stability were greatly enhanced when compared with the pure, non-modified one [24]. Griboval-Constant et al. supported $\mathrm{Ru}$ and $\mathrm{Co}$ on the molybdenum carbide for Fischer-Tropsch synthesis and also found the promotion effects[25]. However, in these studies, it should be noted that the metal was in fact supported on the passivated surface of the molybdenum carbide (i.e., oxide surface), but not on the carbide surface. In order to synthesize and characterize metal-doped carbide materials where the metals interact directly with the native surfaces of carbides, Schweitzer et al., directly deposited Pt onto the carbide surface using aqueous wet impregnation method, avoiding exposure of the carbide surface to $\mathrm{O}_{2}$. When this catalyst was applied for water gas shift reaction, they found that it had high activity for this reaction due to the strong metal-carbide interactions and uniform Pt particle dispersion on the carbide surface[26]. When it was used for the $\mathrm{SRM}$ in the presence of $5 \mathrm{ppm} \mathrm{H}_{2} \mathrm{~S}$, a higher degree of tolerance to sulfur during SRM was found[27]. However, this method is very complex, and it cannot be used in practical process.

In the present study, a facile method was developed to support various metals on molybdenum carbide by in-situ carburization metal-loading molybdenum oxide $\left(\mathrm{M}-\mathrm{MoO}_{\mathrm{x}}\right)$ via temperature-programmed reaction $(\mathrm{TPR})$ with a final temperature of 
$700{ }^{\circ} \mathrm{C}$ in a reaction gas mixture of $20 \% \mathrm{CH}_{4} / \mathrm{H}_{2}$. The prepared catalysts were characterized using X-ray diffraction (XRD), Brunauer-Emmett-Teller (BET) surface area analyzer, Scanning Electron Microscope (SEM) and Transmission Electron Microscope (TEM) and applied for the SRM at different temperatures. The effects of Pt doping amount, weight hourly space velocity (WHSV) on the methanol conversion, hydrogen yield and selectivity were investigated. A long-time stability of as-prepared Pt-doped molybdenum carbide was also tested at different temperatures.

\section{Experimental}

For preparation of metal doped molybdenum oxide $\left(\mathrm{M}-\mathrm{MoO}_{\mathrm{x}}\right)(\mathrm{M}$ : $\mathrm{Pt}, \mathrm{Fe}, \mathrm{Co}$, and Ni), Firstly, aqueous solutions of $\left(\mathrm{NH}_{4}\right)_{6} \mathrm{Mo}_{7} \mathrm{O}_{24} \cdot 4 \mathrm{H}_{2} \mathrm{O}$ mixed with $\mathrm{H}_{2} \mathrm{PtCl}_{6} \cdot 6 \mathrm{H}_{2} \mathrm{O}$, $\mathrm{Fe}\left(\mathrm{NO}_{3}\right)_{3} \cdot 9 \mathrm{H}_{2} \mathrm{O}, \mathrm{Co}\left(\mathrm{NO}_{3}\right)_{2} \cdot 6 \mathrm{H}_{2} \mathrm{O}, \mathrm{Ni}\left(\mathrm{NO}_{3}\right)_{2} \cdot 6 \mathrm{H}_{2} \mathrm{O}$, respectively, were stirred at $80{ }^{\circ} \mathrm{C}$ for $4 \mathrm{~h}$, and then the resultant slurry was filtered out and dried at $110^{\circ} \mathrm{C}$ for $12 \mathrm{~h}$ and finally calcined at $500{ }^{\circ} \mathrm{C}$ for $4 \mathrm{~h}$ in air. Carburization of $\mathrm{M}-\mathrm{MoO}_{\mathrm{x}}$ and the $\mathrm{SRM}$ reaction were carried out in the same fixed-bed quartz micro-reactor with an inner diameter of $8 \mathrm{~mm}$. M-MoO powder was placed on a porous quartz plate in the micro-reactor, and then carburized in $\mathrm{CH}_{4} / \mathrm{H}_{2}\left(20 \mathrm{vol} \% \mathrm{CH}_{4}\right)$ flow to $\mathrm{M}_{\mathrm{x}} \mathrm{Moy}_{\mathrm{y}} \mathrm{C}$ with a successive temperature-programmed reaction (TPR) process [28,29]: the carburiztion temperature was raised from the room temperature (RT) to $300{ }^{\circ} \mathrm{C}$ in $1 \mathrm{~h}$, and then increased to $700{ }^{\circ} \mathrm{C}$ at a rate of $1{ }^{\circ} \mathrm{C} / \mathrm{min}$, and subsequently kept at $700{ }^{\circ} \mathrm{C}$ for $2 \mathrm{~h}$. As-obtained material was cooled down to $\mathrm{RT}$ in the $\mathrm{CH}_{4} / \mathrm{H}_{2}$ flow and finally passivated 
in $1 \% \mathrm{O}_{2} / \mathrm{Ar}$ for $12 \mathrm{~h}$. In this study, various metal doped molybdenum carbide with a same stoichiometric composition of $\mathrm{M}_{1.6 \mathrm{Mo}} \mathrm{M}_{4} \mathrm{C}$ were prepared. Pt doped molybdenum carbides with stoichiometric compositions of $\mathrm{Pt}_{1.2} \mathrm{Mo98.8}$, $\mathrm{Pt}_{0.8} \mathrm{Mo99.2} \mathrm{C}$ and $\mathrm{Pt}_{0.4 \mathrm{Mog9.6}} \mathrm{C}$ were also prepared. For comparison, $\mathrm{MoO}_{3}$ powder was obtained by calcinations of $\left(\mathrm{NH}_{4}\right)_{6} \mathrm{Mo}_{7} \mathrm{O}_{24} \cdot 4 \mathrm{H}_{2} \mathrm{O}$ at $500{ }^{\circ} \mathrm{C}$ for $4 \mathrm{~h}$ in air and then also carburized using the same method as the above to get $\beta-\mathrm{Mo}_{2} \mathrm{C}$ catalyst.

The crystal structures of the catalysts before and after reactions were determined by X-ray diffraction (XRD 610, Shimadzu, Japan). The radiation used was CuK $\alpha$ and the operating potential was $30 \mathrm{KV}$, current $30 \mathrm{~mA}$, and the scanning rate $4^{\circ} / \mathrm{min}$. BET surface areas were measure at $77 \mathrm{~K}$ using a Bel-sorp 28SA automatic absorption instrument. The microstructure and morphology were characterized with a SEM (S-800, Hitachi, Japan). TEM images were obtained using a JEM-2100F transmission electron microscope JEOL operating at $200 \mathrm{kV}$.

Catalytic performances of as-prepared pure molybdenum carbide and the metal loaded molybdenum carbide for the SRM were evaluated in the same micro-reactor with an inner diameter of $6 \mathrm{~mm}$. Prior to the reaction, the catalyst was pretreated with $15 \%$ $\mathrm{CH}_{4} / \mathrm{H}_{2}$ at $590{ }^{\circ} \mathrm{C}$ for $2 \mathrm{~h}$ to reduce the surface oxide. The total amount of the catalyst used for the steam reforming of methanol was approximately $0.4 \mathrm{~g}$. Two WHSVs, i.e., 9000 and $18000 \mathrm{~cm}^{3} \mathrm{~g}^{-1} \mathrm{~h}^{-1}$ were selected. Methanol and water mixture with a mole ratio of 1:1 was injected into the reactor with a syringe pump. It was vaporized in a pre-heater containing a $\mathrm{ZrO}_{2}$ beads and carried by Ar gas flow. A cold trap was set at the 
exit of the reactor in order to remove unconverted liquid hydrocarbons and steam prior to the analysis of the gas compositions in the product. The gases produced were analyzed using a gas chromatograph (Agilent 7890A GC system).

The performances of the as-prepared catalysts were characterized in terms of methanol conversion and hydrogen yield. The methanol conversion was defined as the molar ratio of the gaseous carbon compounds $\left(\mathrm{CH}_{4}, \mathrm{CO}\right.$, and $\left.\mathrm{CO}_{2}\right)$ in the product stream to the feed methanol. The hydrogen selectivity was defined as the mole ratio of the produced hydrogen to the theoretical amount that could be produced from the feed methanol based on eq.(1). The mole fraction of a product component was defined as the mole ratio of this specific product to the total gaseous products.

\section{Results and discussion}

\subsection{Characterization of fresh catalysts}

Fig. 1 shows the XRD patterns of $\beta-\mathrm{Mo}_{2} \mathrm{C}$ and various metal doped molybdenum carbide catalysts. The peaks at $2 \theta$ of $34.8^{\circ}, 38.4^{\circ}, 39.8^{\circ}, 52.5^{\circ}, 61.9^{\circ}$ and $74.9^{\circ}$ are attributed to the presence of hexagonal $\beta-\mathrm{Mo}_{2} \mathrm{C}$ (hcp crystal structure). The peaks at $2 \theta$ of $37.1^{\circ}, 42.8^{\circ}, 62.4^{\circ}, 74.5^{\circ}$ and $78.4^{\circ}$ are attributed to $\alpha-\mathrm{MoC}_{1-\mathrm{x}}$ (fcc crystal structure). No peak corresponding to metal and its oxide was found for $\mathrm{Fe}, \mathrm{Co}$, and $\mathrm{Ni}$ doped catalysts, but a small peak corresponding to Pt was found in Pt doped catalyst with the increase in Pt doping amount (Fig.1b). Notably, as shown in Fig.1(a), using the present method, when Fe, Co, and Ni precursors were applied, $\beta-\mathrm{Mo}_{2} \mathrm{C}$ phase was formed in the 
final catalysts during the temperature programmed reactions (TPRe) process. However, the doping of $\mathrm{Pt}$ resulted in the $\alpha-\mathrm{MoC}_{1-\mathrm{x}}$ phase appeared with $\beta-\mathrm{Mo}_{2} \mathrm{C}$ phase, and with the increase in $\mathrm{Pt}$ doping amount, the peaks corresponding to $\alpha-\mathrm{MoC}_{1-\mathrm{x}}$ phase became more obvious, suggesting more $\alpha-\mathrm{MoC}_{1-\mathrm{x}}$ phase produced in the final catalyst. In general, the direct carburization of $\mathrm{MoO}_{3}$ with $\mathrm{CH}_{4} / \mathrm{H}_{2}$ produces $\beta-\mathrm{Mo}_{2} \mathrm{C}$, which is a thermodynamically stable phase under the preparation conditions, but the carbide obtained via nitride (fcc $\gamma$-Mo2 $\mathrm{N}$, produced from the TPRe of $\mathrm{MoO}_{3}$ with $\mathrm{NH}_{3}$ ) always has the metastable fcc $\alpha-\mathrm{MoC}_{1-\mathrm{x}}$ phase[30]. Jung et al. investigated the effect of various transition metals on the solid-state transformation of $\mathrm{MoO}_{3}$ to molybdenum carbides in the $\mathrm{CH}_{4} / \mathrm{H}_{2}$ gas flow, and also found that the doping of $\mathrm{Co}$ or $\mathrm{Cu}$ resulted in the formation of hexagonal $\beta-\mathrm{Mo}_{2} \mathrm{C}$ as in the absence of any transition metal while the doping of Pt or Pd produced cubic $\alpha-\mathrm{MoC}_{1-\mathrm{x}}$ phase[31]. It was proposed that the loading of $\mathrm{Pt}$ or $\mathrm{Pd}$ to $\mathrm{MoO}_{3}$ could reduce the initial reduction temperature and the solid-transformation process become a topotatic transformation through a $\mathrm{MoO}_{\mathrm{x}} \mathrm{C}_{\mathrm{y}}$ intermediate phase, leading to the formation of the metastable $\alpha-\mathrm{MoC}_{1-\mathrm{x}}$ phase. However, loading of some other transition metals such as Fe, Co and Ni in this study, $\mathrm{MoO}_{2}$ and other suboxides other than $\mathrm{MoO}_{\mathrm{x}} \mathrm{C}_{\mathrm{y}}$ could be formed as solid intermediates during the carburization, and in this case, two consecutive processes occurred: the reduction of $\mathrm{MoO}_{3}$ to $\mathrm{MoO}_{2}$ by $\mathrm{H}_{2}$ at a relatively low temperature without involving $\mathrm{CH}_{4}$, followed by the simultaneous further reduction and carburization of the intermediate $\mathrm{MoO}_{2}$ to molybdenum carbide with a nontopotactic transformation route, 
resulting in the formation of $\beta-\mathrm{Mo}_{2} \mathrm{C}$ phase[30,31]. SEM images of $\beta-\mathrm{Mo}_{2} \mathrm{C}$,

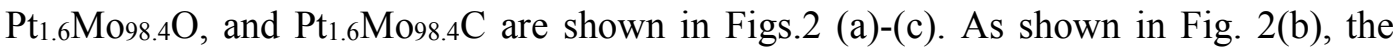
morphology of $\mathrm{MoO}_{3}$ was in platelet form. After carburization, the morphology of $\beta-\mathrm{Mo}_{2} \mathrm{C}$ (Fig.2(a)) changed to agglomerated isotropic particles by breaking the platelet, and was completely different from the morphology of its parent $\mathrm{MoO}_{3}$, indicating that the nontopotatic transformation was taken place during the carburization process. In the case of $\mathrm{Pt}_{1.6 \mathrm{Mo}} \mathrm{M} .4 \mathrm{C}$, however, the morphology of some molybdenum carbides kept platelet form as their parent $\mathrm{MoO}_{3}$ (Fig.2(c)), indicating that the topotatic transformation occurred during the carburization process. However, from the Fig. 2c, it should be noted that some agglomerated isotropic particles also existed, implying that the nontopotatic transformation also occurred during the carburization process in the presence of Pt. Insets of Figs 2(b) and (c) show TEM images of $\mathrm{Pt}_{1.6 \mathrm{Mog} .4 \mathrm{O}}$ and

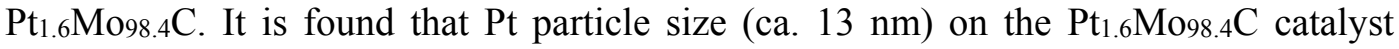
(inset of Fig. 2(c)) maintained almost unchanged when compared with that on the

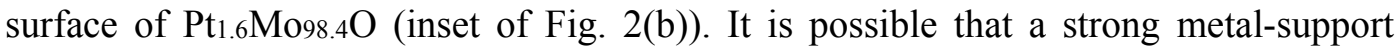
interaction (SMSI) between the Pt and $\mathrm{Mox}_{\mathrm{x}} \mathrm{C}_{\mathrm{y}}$ could trap the Pt particles, and prevent it to grow up.

BET surface area $\left(\mathrm{S}_{\mathrm{BET}}\right)$ of the pure $\mathrm{Mo}_{2} \mathrm{C}$ and metal modified molybdenum carbide catalysts are summarized in Table 1 . One can see that Pt modified sample had the highest BET surface area $\left(40 \mathrm{~m}^{2} / \mathrm{g}\right)$, approximately 4 times higher than the pure molybdenum carbide $\left(10 \mathrm{~m}^{2} / \mathrm{g}\right)$. Comparing to the pure $\mathrm{Mo}_{2} \mathrm{C}$, the BET surface area 
increased when metal was doped. This increase in surface area might be attributed to the lower temperature reduction of $\mathrm{MoO}_{3}$ after metal doping [29, 31]. In general, the particle size should be determined by the mobility of the metal atoms, thus, low reduction temperature could limit the mobility and lead to smaller particles with high surface areas.

\subsection{Performances of various metal doped catalysts}

Fig.3(a) shows the effect of reaction temperature on methanol conversions for the SRMs over as-prepared $\mathrm{M}_{1.6} \mathrm{Mog8.4} \mathrm{C}(\mathrm{M}=\mathrm{Fe}, \mathrm{Co}, \mathrm{Ni}$ and $\mathrm{Pt})$ and $\beta-\mathrm{Mo}_{2} \mathrm{C}$ without metal doping under a WHSV of $9000 \mathrm{~cm}^{3} \mathrm{~g}^{-1} \mathrm{~h}^{-1}$ and steam-to-carbon molar ratio of one. Since the SRM reaction is endothermic reaction which is generally more favorable at high temperatures, the methanol conversion increases with the increase in reaction temperature. Compared with the undoped $\beta-\mathrm{Mo}_{2} \mathrm{C}$, the metal doped catalysts showed higher conversion due to the synergistic interaction of the dopped metal particles and the carbide substrate. Furthermore, Pt doped molybdenum carbide catalyst exhibited higher catalytic activity than other metal doped ones, and the methanol conversion reached $100 \%$ at a reaction temperature as low as $200{ }^{\circ} \mathrm{C}$ at the beginning of reaction. However, for Fe, Co, and Ni doped catalysts, the similar conversion can be only found at a temperature over $300{ }^{\circ} \mathrm{C}$ or higher. Also, it should be noted that the methanol conversion reached $60 \%$ for $\mathrm{Pt}_{1.6} \mathrm{Mog8.4} \mathrm{C}$ catalyst even at a reaction temperature of 150 ${ }^{\circ} \mathrm{C}$, suggesting that $\mathrm{Pt}$ doped molybdenum carbide is a perspective catalyst for methanol 
conversion at low temperatures. Fig.3(b) shows effect of Pt doping amount on the methanol conversion with the increase in temperature. The catalytic activity of

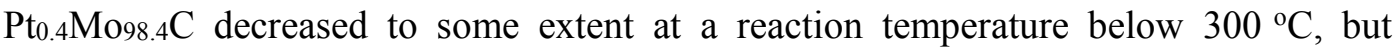
$\mathrm{Pt}_{0.8 \mathrm{M}} \mathrm{M} 99.2 \mathrm{C}$ and $\mathrm{Pt}_{1.2} \mathrm{Mo98.8} \mathrm{C}$ showed a similar catalytic activity as that of $\mathrm{Pt}_{1.6} \mathrm{Mo} 98.4 \mathrm{C}$. It suggested that Pt doping amount could be reduced for a practical catalyst.

Fig. 4 shows product compositions for the SRM over $\beta-\mathrm{Mo}_{2} \mathrm{C}$ and various metal doped molybdenum carbide catalysts at the same operation conditions as those in Fig.3. One can see that $\mathrm{H}_{2}$ and $\mathrm{CO}_{2}$ were the main components in the gas products, together with a small amount of $\mathrm{CO}$ and $\mathrm{CH}_{4}$. In this study, no other products such as dimethyl ether, methyl formate or ethane were detected from the SRM over any of the catalysts tested. It should be noted that the concentration of $\mathrm{CO}$ in the product was below $5 \%$ for metal $(\mathrm{Fe}, \mathrm{Co}, \mathrm{Ni}, \mathrm{Pt})$ modified carbide catalysts while the $\mathrm{CO}$ content was over $10 \%$ at $400{ }^{\circ} \mathrm{C}$, indicating that metal doping enhanced water gas shift (WGS, Eq.(3)) reaction over the molybdenum carbide surface. Several researches on WGS reaction also identified it $[33,34]$. The WGS is a critical and important step in the removal of CO from reformate and often accompanies with the steam reforming reactions for the production of $\mathrm{H}_{2}$. $\mathrm{CO}$ is a poison for fuel cell catalysts and has to be removed or converted in a practical reforming process for fuel cell use. Therefore, it is meaningful to develop molybdenum carbide based catalysts for the SRM, WGS, and others for $\mathrm{H}_{2}$ production.

$\mathrm{CH}_{4}$ is another unwanted byproduct for the present study. $\mathrm{CH}_{4}$ compositions in the 
products as shown in Fig.4 were summarized in Fig.5. Compared with metal doped molybdenum carbide, it is obvious that more $\mathrm{CH}_{4}$ was generated from the $\mathrm{SRM}$ over undoped $\beta-\mathrm{Mo}_{2} \mathrm{C}$ catalyst with the increase in reaction temperature, and the concentration was raised to approximately $13 \%$ at $350{ }^{\circ} \mathrm{C}$. Theoretically, the final $\mathrm{H}_{2}$ percentage in the product should be the result of the competition among the SRM (Eq.(1)),WGS (Eq.(3)) and methanation (Eq.(4)) reactions. 1 mol methane production could result in a loss of 4 mol hydrogen. Therefore, it is expected that the methanation reaction can be hindered so that more hydrogen is extracted from steam as well as methanol in the SRM process. As indicated in Figs. 3 and 4, the methanation reaction was obviously hindered by the doping of metal. Especially, it should be noted that more hydrogen but less $\mathrm{CH}_{4}$ were produced over Pt doped molybdenum carbide even at high reaction temperatures, indicating that the methanation reaction could be effectively hindered by the addition of Pt on molybdenum carbide.

Fig.6 shows effects of WHSV on the methanol conversion, $\mathrm{H}_{2}$ selectivity and

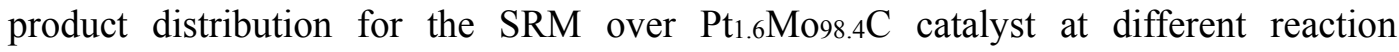
temperatures. One can see that the increase of WHSV reduced the methanol conversion, especially at low reaction temperature. However, with the increase in WHSV, the concentration of $\mathrm{CH}_{4}$ decreased while the $\mathrm{H}_{2}$ selectivity increased, especially at high reaction temperatures.

\subsection{Catalytic stability}


Fig.7 shows the catalytic stability of $\beta-\mathrm{Mo}_{2} \mathrm{C}$ and $\mathrm{Pt}_{1.6} \mathrm{Mo98.4} \mathrm{C}$ used for the $\mathrm{SRM}$ at 200 and $400{ }^{\circ} \mathrm{C}$ for $20 \mathrm{~h}$ under a WHSV of $9000 \mathrm{~cm}^{3} \mathrm{~g}^{-1} \mathrm{~h}^{-1}$ and steam-to-carbon molar ratio of one. It is obvious that $\beta-\mathrm{Mo}_{2} \mathrm{C}$ showed fast deactivation with the reaction time so that methanol conversion was lower than $10 \%$ after $10 \mathrm{~h}$ reaction even at a temperature of $400{ }^{\circ} \mathrm{C}$. However, comparing with the $\beta$-Mor $\mathrm{C}, \mathrm{Pt}_{1.6} \mathrm{Mo} 98.4 \mathrm{C}$ showed a high long-term catalytic activity. One can see that the methanol conversion dropped from $100 \%$ to $60 \%$ during the initial reaction period $(4 \mathrm{~h})$ at a reaction temperature of $200{ }^{\circ} \mathrm{C}$, but then maintained stable in the continuous reaction period, in which the methanol conversion kept at the $60 \%$ while the hydrogen production rate kept at 900 $\mu \mathrm{mol} / \mathrm{g} / \mathrm{min}$. The product distribution results also indicated that the product compositions were stable for $20 \mathrm{~h}$, and the molar hydrogen composition kept at approximately $70 \mathrm{~mol} \%$. At a temperature of $400{ }^{\circ} \mathrm{C}$, the reforming activity only suffered from an initial deactivation period where the methanol conversion dropped from $100 \%$ to $85 \%$, and the a stable activity was maintained up to $20 \mathrm{~h}$ and the methanol conversion kept at approximately $85 \%$ with a hydrogen production rate of $1327 \mu \mathrm{mol} / \mathrm{g} / \mathrm{min}$, suggesting that the stability of molybdenum carbide was greatly enhanced by addition of Pt. It should be noted that $\mathrm{Pt}$ was dispersed on $\mathrm{Mo}_{2} \mathrm{C}$ and $\mathrm{Mo}_{2} \mathrm{C}$ itself also provided active sites for the SRM. However, it is found that $\mathrm{Mo}_{2} \mathrm{C}$ is easily deactivated in the SRM process as shown in Fig.7. It has been previously reported that the deactivation of $\mathrm{Mo}_{2} \mathrm{C}$ is mainly caused by the oxidation of $\mathrm{Mo}_{2} \mathrm{C}$ into inactive molybdenum dioxide[33], however, as shown in Fig.8, the XRD pattern of the spent 
catalyst had no evidence of $\mathrm{MoO}_{2}$ and other molybdenum oxide formation. Although the oxidation of the $\mathrm{Mo}_{2} \mathrm{C}$ was not observed in the XRD pattern of spent catalyst, the surface oxidation should be possible for this reaction. The regeneration experiment for the used $\beta-\mathrm{Mo}_{2} \mathrm{C}$ indicated that the activity of deactivated catalyst recovered after it was treated at $15 \% \mathrm{CH}_{4} / \mathrm{H}_{2}$ at $590{ }^{\circ} \mathrm{C}$ for $2 \mathrm{~h}$. Furthermore, other reasons for the deactivation of $\mathrm{Mo}_{2} \mathrm{C}$ such as coke formation on the catalyst surface should be also possible. On the other hand, as shown in Fig. 7, methanol conversion decreased only at the beginning of reaction for the Pt doped $\mathrm{Mo}_{2} \mathrm{C}$. According to the XRD results as shown in Figs. 1 and 8, it is found that the peak of $\beta-\mathrm{Mo}_{2} \mathrm{C}$ at $39.8^{\circ}$ increased while the peak intensity of $\alpha-\mathrm{MoC}_{1-\mathrm{x}}$ decreased for the spent catalyst, suggesting that the unstable $\alpha-\mathrm{MoC}_{1-\mathrm{x}}$ transformed to the stable $\beta-\mathrm{Mo}_{2} \mathrm{C}$ during the beginning reaction time, resulting in the methanol conversion decreased to some extent. Furthermore, the surface area and catalytic activity of $\beta-\mathrm{Mo}_{2} \mathrm{C}$ are generally lower than those of $\alpha-\mathrm{MoC}_{1-\mathrm{x}}$. The decrease in methanol conversion at the beginning should be attributed to the phase transformation from $\alpha-\mathrm{MoC}_{1-\mathrm{x}}$ to $\beta-\mathrm{Mo}_{2} \mathrm{C}$. Other reseachers also found the similar phenomena on the metane dry refoming over $\mathrm{Mo}_{2} \mathrm{C}$ based catalysts[29, 35]. Other reasons for the conversion decreased such as coke formation on the catalyst surface should be also possible. Further study is necessary for this interesting phenomenon.

\section{Conclusions}

Steam reforming of methanol was performed on various transition metals $(\mathrm{M}=\mathrm{Pt}$, 
Fe, Co, and $\mathrm{Ni}$ ) doped on molybdenum carbides by in-situ carburization metal-doped molybdenum oxide $\left(\mathrm{M}-\mathrm{MoO}_{\mathrm{x}}\right)$ via temperature-programmed reaction (TPR) methods. Comparing with the undoped molybdenum carbide, metal-doped molybdenum carbides showed higher methanol conversion and hydrogen yield. Especially, Pt doped molybdenum carbide showed the highest catalytic activity and selectivity among the prepared metal doped catalysts and methanol conversion reached $100 \%$ even at a temperature as low as $200{ }^{\circ} \mathrm{C}$, and remained a long-time stability at a temperature in the range of $200-400{ }^{\circ} \mathrm{C}$. It is found that weight hourly space velocity had great effects on the methanol conversion and $\mathrm{H}_{2}$ selectivity. XRD analysis results indicated that $\beta-\mathrm{Mo}_{2} \mathrm{C}$ phase was formed in the case of $\mathrm{Fe}, \mathrm{Co}$, or $\mathrm{Ni}$ doping while $\alpha-\mathrm{Mo}_{2} \mathrm{C}_{1-\mathrm{x}}$ phase was appeared with the $\beta-\mathrm{Mo}_{2} \mathrm{C}$ phase in the case of Pt doping. With the increase in Pt doping amount, more $\alpha-\mathrm{Mo}_{2} \mathrm{C}_{1-\mathrm{x}}$ phase was produced.

\section{Acknowledgements}

This work is supported by Japan Science and Technology Agency (JST), Japan and Aomori City Government. Mr Ma thanks the State Scholarship Fund of China Scholarship Council (2012). The authors also thank Dr Yutaka Kasai and Dr Seiji Kakuta at Aomori Prefectural Industrial Technology Research Center for their technical support on experiments.

\section{References}


[1] Barthos R, Solymosi F. Hydrogen production in the decomposition and steam reforming of methanol on $\mathrm{Mo}_{2} \mathrm{C} /$ carbon catalysts. J Catal 2007;249:289-99.

[2] Amphlett J, Evans M, Mann R, Weir R. Hydrogen production by the catalytic steam reforming of methanol: Part 2: Kinetics of methanol decomposition using girdler G66B catalyst. Can J Chem Eng 2009;63:605-11.

[3] Sá S, Silva H, Brandão L, Sousa JM, Mendes A. Catalysts for methanol steam reforming-A review. Appl Catal B Environ 2010;99:43-57.

[4] Jones SD, Neal LM, Hagelin-Weaver HE. Steam reforming of methanol using $\mathrm{Cu}-\mathrm{ZnO}$ catalysts supported on nanoparticle alumina. Appl Catal B Environ 2008;84:631-42.

[5] Zhang XR, Wang LC, Yao CZ, Cao Y, Dai WL, He HY. A highly efficient $\mathrm{Cu} / \mathrm{ZnO} / \mathrm{Al}_{2} \mathrm{O}_{3}$ catalyst via gel-coprecipitation of oxalate precursors for low-temperature steam reforming of methanol. Calat Lett 2005;102:183-90.

[6] Rameshan C, Stadlmayr W, Penner S, Lorenz H, Memmel N, Hävecker M. Hydrogen Production by Methanol Steam Reforming on Copper Boosted by Zinc-Assisted Water Activation. Angew Chem Int Ed 2012;51:3002-6.

[7] Kurr P, Kasatkin I, Girgsdies F, Trunschke A, Schlögl R, Ressler T. Microstructural characterization of $\mathrm{Cu} / \mathrm{ZnO} / \mathrm{Al}_{2} \mathrm{O}_{3}$ catalysts for methanol steam reforming-A comparative study. Appl Catal A Gen 2008;348:153-64.

[8] Yi N, Si R, Saltsburg H, Flytzani-Stephanopoulos M. Active gold species on cerium oxide nanoshapes for methanol steam reforming and the water gas shift reactions. Energ 
Environ Sci 2010;3:831-7.

[9] Pongstabodee S, Monyanon S, Luengnaruemitchai A. Hydrogen production via methanol steam reforming over $\mathrm{Au} / \mathrm{CuO}, \mathrm{Au} / \mathrm{CeO}_{2}$, and $\mathrm{Au} / \mathrm{CuO}-\mathrm{CeO}_{2}$ catalysts prepared by deposition-precipitation. J Ind Eng Chem 2012;18:831-7

[10] Ranganathan ES, Bej SK, Thompson LT. Methanol steam reforming over Pd/ZnO and $\mathrm{Pd} / \mathrm{CeO}_{2}$ catalysts. Appl Catal A Gen 2005;289:153-62.

[11] Penner S, Lorenz H, Jochum W, Stöger-Pollach M, Wang D, Rameshan C. $\mathrm{Pd} / \mathrm{Ga}_{2} \mathrm{O}_{3}$ methanol steam reforming catalysts: Part I. Morphology, composition and structural aspects. Appl Catal A Gen 2009;358:193-202.

[12] Wang Y, Zhang J, Xu H, Bai X. Reduction of Pd/ZnO Catalyst and Its Catalytic Activity for Steam Reforming of Methanol. Chinese J Catal 2007;28:234-8.

[13] Eswaramoorthi I, Dalai A. A comparative study on the performance of mesoporous SBA-15 supported Pd-Zn catalysts in partial oxidation and steam reforming of methanol for hydrogen production. Int J Hydrogen Energy 2009;34:2580-90.

[14] Pojanavaraphan C, Luengnaruemitchai A, Gulari E. Effect of catalyst preparation on $\mathrm{Au} / \mathrm{Ce}_{1-\mathrm{x}} \mathrm{Zr}_{\mathrm{x}} \mathrm{O}_{2}$ and $\mathrm{Au}-\mathrm{Cu} / \mathrm{Ce}_{1-\mathrm{x}} \mathrm{Zr}_{\mathrm{x}} \mathrm{O}_{2}$ for steam reforming of methanol. Int $\mathrm{J}$ Hydrogen Energy 2012;38:1348-62

[15] Lee JS, Yeom MH, Park KY, Nam IS, Chung JS, Kim YG. Preparation and benzene hydrogenation activity of supported molybdenum carbide catalysts. J Catal 1991;128:126-36.

[16] Blekkan EA, Pham-Huu C, Ledoux MJ, Guille J. Isomerization of n-heptane on an 
oxygen-modified molybdenum carbide catalyst. Ind Eng Chem Res 1994;33:1657-64.

[17] Zhang A, Zhu A, Chen B, Zhang S, Au C, Shi C. In-situ synthesis of nickel modified molybdenum carbide catalyst for dry reforming of methane. Catal Commun 2011;12:803-7.

[18] Brungs AJ, York AP, Claridge JB, Márquez-Alvarez C, Green ML. Dry reforming of methane to synthesis gas over supported molybdenum carbide catalysts. Calat Lett 2000;70:117-22.

[19] Széchenyi A, Solymosi F. Production of hydrogen in the decomposition of ethanol and methanol over unsupported $\mathrm{Mo}_{2} \mathrm{C}$ catalysts. J Phys Chem C. 2007;111:9509-15.

[20] Lin SY, Thomson WJ, Hagensen TJ, Ha SY. Steam reforming of methanol using supported Mo2C catalysts. Appl Catal A Gen 2007;318:121-7.

[21] Koós Á, Barthos R, Solymosi F. Reforming of Methanol on a K-Promoted Mo2C/Norit Catalyst. J Phys Chem C. 2008;112:2607-12.

[22] Barthos R, Széchenyi A, Solymosi F. Efficient $\mathrm{H}_{2}$ production from ethanol over $\mathrm{Mo} 2 \mathrm{C} / \mathrm{C}$ nanotube catalyst. Calat Lett 2008;120:161-5.

[23] Kelly TG, Chen JG. Metal overlayer on metal carbide substrate: unique bimetallic properties for catalysis and electrocatalysis. Chem Soc Rev 2012;41:8021-34.

[24] Lewandowski M, Szymańska-Kolasa A, Da Costa P, Sayag C. Catalytic performances of platinum doped molybdenum carbide for simultaneous hydrodenitrogenation and hydrodesulfurization. Catal Today 2007;119:31-4.

[25] Griboval-Constant A, Giraudon JM, Leclercq G, Leclercq L. Catalytic behaviour of 
cobalt or ruthenium supported molybdenum carbide catalysts for FT reaction. Appl Catal A Gen 2004;260:35-45.

[26] Schweitzer NM, Schaidle JA, Ezekoye OK, Pan X, Linic S, Thompson LT. High activity carbide supported catalysts for water gas shift. J Am Chem Soc 2011;133:2378-81.

[27] Lausche AC, Schaidle JA, Thompson LT. Understanding the effects of sulfur on $\mathrm{Mo}_{2} \mathrm{C}$ and $\mathrm{Pt} / \mathrm{Mo}_{2} \mathrm{C}$ catalysts: Methanol steam reforming. Appl Catal A Gen 2011;401:29-36.

[28] Ma YF, Guan GQ, Shi C, Zhu A, Hao X, Kasai Y, Abudula A. Steam reforming of methanol to produce hydrogen over molybodenum carbide-based catalysts at low temperatures. In: Saha BB, Koyama M, Takata Y, editors. Innovative Materials for Processes in Energy Systems, Fukuoka, Japan: Touka Shobo; 2013, p.45-59.

[29] Shi C, Zhang A, Li X, Zhang S, Zhu A, Ma Y, et al. Ni-modified Mo2C catalysts for methane dry reforming. Appl Catal A Gen 2012;431:164-70.

[30] Lee J, Volpe L, Ribeiro F, Boudart M. Molybdenum carbide catalysts: II. Topotactic synthesis of unsupported powders. J Catal 1988;112:44-53.

[31] Jung KT, Kim WB, Rhee CH, Lee JS. Effects of transition metal addition on the solid-state transformation of molybdenum trioxide to molybdenum carbides. Chem Mater 2004;16:307-14.

[32] Li S, Kim WB, Lee JS. Effect of the reactive gas on the solid-state transformation of molybdenum trioxide to carbides and nitrides. Chem Mater 1998;10:1853-62. 
[33] Patt J, Moon DJ, Phillips C, Thompson L. Molybdenum carbide catalysts for water-gas shift. Calat Lett 2000;65:193-5.

[34] Nagai M, Matsuda K. Low-temperature water-gas shift reaction over cobalt-molybdenum carbide catalyst. J Catal 2006;238:489-96.

[35] Tsuji M, Miyao T, Naito S. Remarkable support effect of $\mathrm{ZrO}_{2}$ upon the $\mathrm{CO}_{2}$ reforming of $\mathrm{CH}_{4}$ over supported molybdenum carbide catalysts. Calat Lett 2000;69:195-8. 


\section{Figure captions}

Fig.1 (a) XRD patterns of metal doped molybdenum carbide catalysts; (b) XRD patterns of Pt doped molybdenum carbide with different doping amount

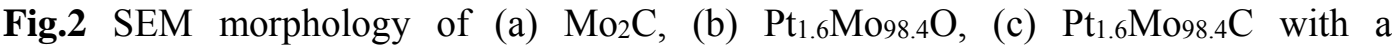
magnification of 10000. Inserts in (b) and (c): Bright-field TEM photographs of Pt.

Fig.3 (a) Catalytic performances of metal doped molybdenum carbide for SRM reaction at different temperatures; (b) Catalytic performances of Pt doped molybdenum carbide with different doping amount

Fig.4 Product compositions for SRM reaction over as-prepared catalysts

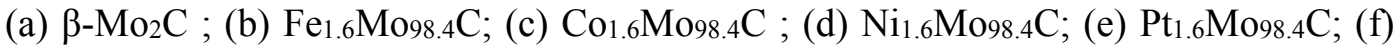
$\mathrm{Pt}_{0.8 \mathrm{Mog9.2}} \mathrm{C}$.

Fig.5 $\mathrm{CH}_{4}$ composition in the product of SRM reaction over as-prepared catalysts showed in Fig.4.

Fig.6 (a) Effect of weight hourly space velocity on methanol conversion and $\mathrm{H}_{2}$ selectivity; (b) Effect of weight hourly space velocity on product compositions

Fig.7 Time-on-stream testing of $\beta-\mathrm{Mo}_{2} \mathrm{C}$ and $\mathrm{Pt}_{1.6 \mathrm{Mo}} \mathrm{M}_{4.4} \mathrm{C}$ catalysts for $\mathrm{SRM}$ reaction at 200 and $400{ }^{\circ} \mathrm{C}$

Fig.8 XRD patterns of the spent catalysts after the experiments shown in Fig.7
(a) $\beta-\mathrm{Mo}_{2} \mathrm{C}-400{ }^{\circ} \mathrm{C}$;

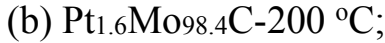

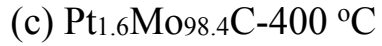


Table 1 BET surface areas of $\beta-\mathrm{Mo}_{2} \mathrm{C} ; \mathrm{Fe}_{1.6} \mathrm{Mo} 98.4 \mathrm{C} ; \mathrm{Co} .6 \mathrm{Mo} 98.4 \mathrm{C} ; \mathrm{Ni} 1.6 \mathrm{Mog8.4}$ C; $\mathrm{Pt}_{1.6 \mathrm{Mo98.4}} \mathrm{C}$

\begin{tabular}{|c|c|c|c|}
\hline Catalysts & $\operatorname{BET}\left(\mathrm{m}^{2} / \mathrm{g}\right)$ & Catalysts & $\operatorname{BET}\left(\mathrm{m}^{2} / \mathrm{g}\right)$ \\
\hline $\mathrm{Mo}_{2} \mathrm{C}$ & 10.2 & $\mathrm{Ni}_{1.6} \mathrm{Mo98.4} \mathrm{C}$ & 19.3 \\
\hline $\mathrm{Fe}_{1.6} \mathrm{Mog8.4} \mathrm{C}$ & 18.3 & $\mathrm{Pt}_{1.6} \mathrm{Mog8.4} \mathrm{C}$ & 40 \\
\hline Co1.6Mo98.4C & 20.6 & & \\
\hline
\end{tabular}




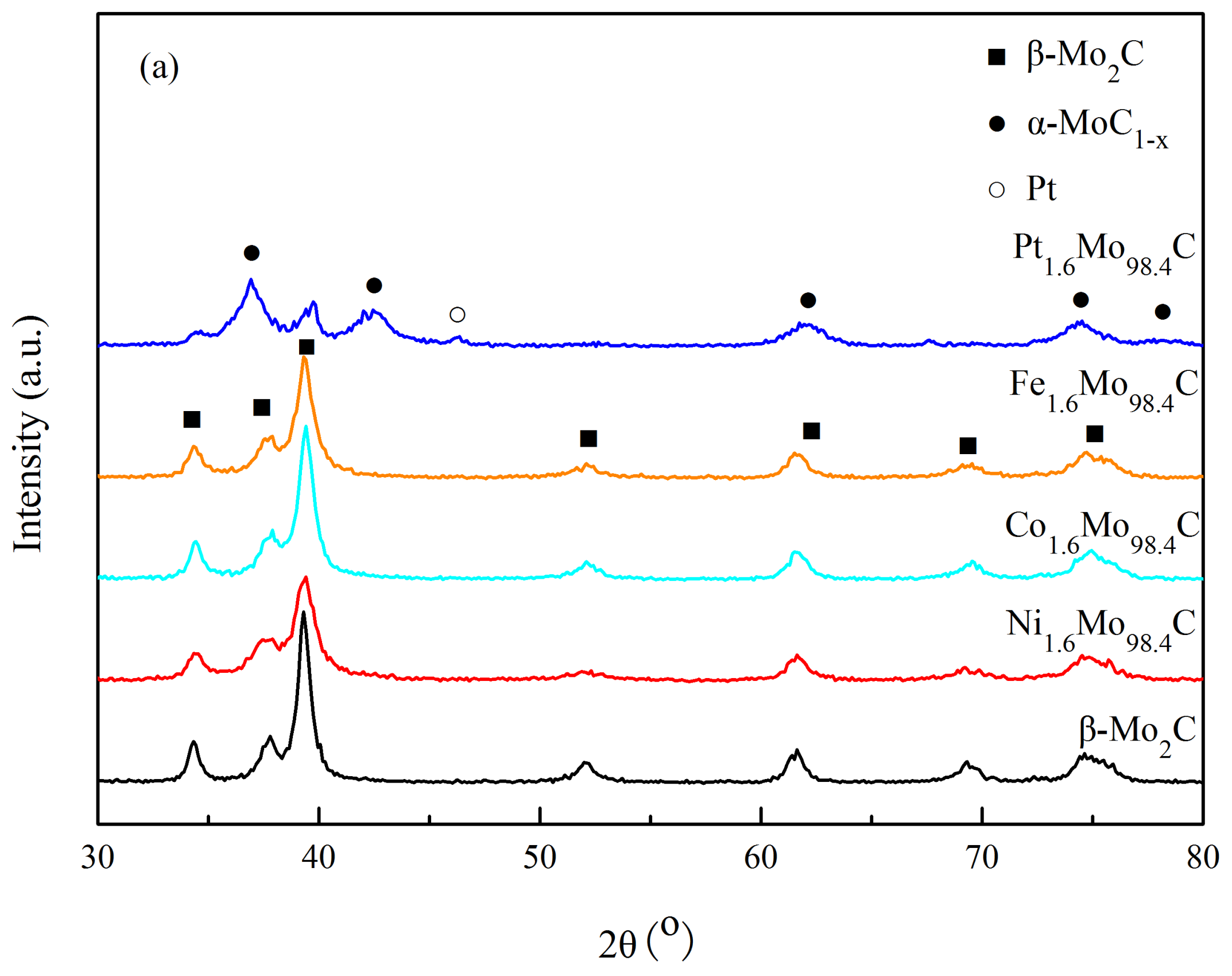




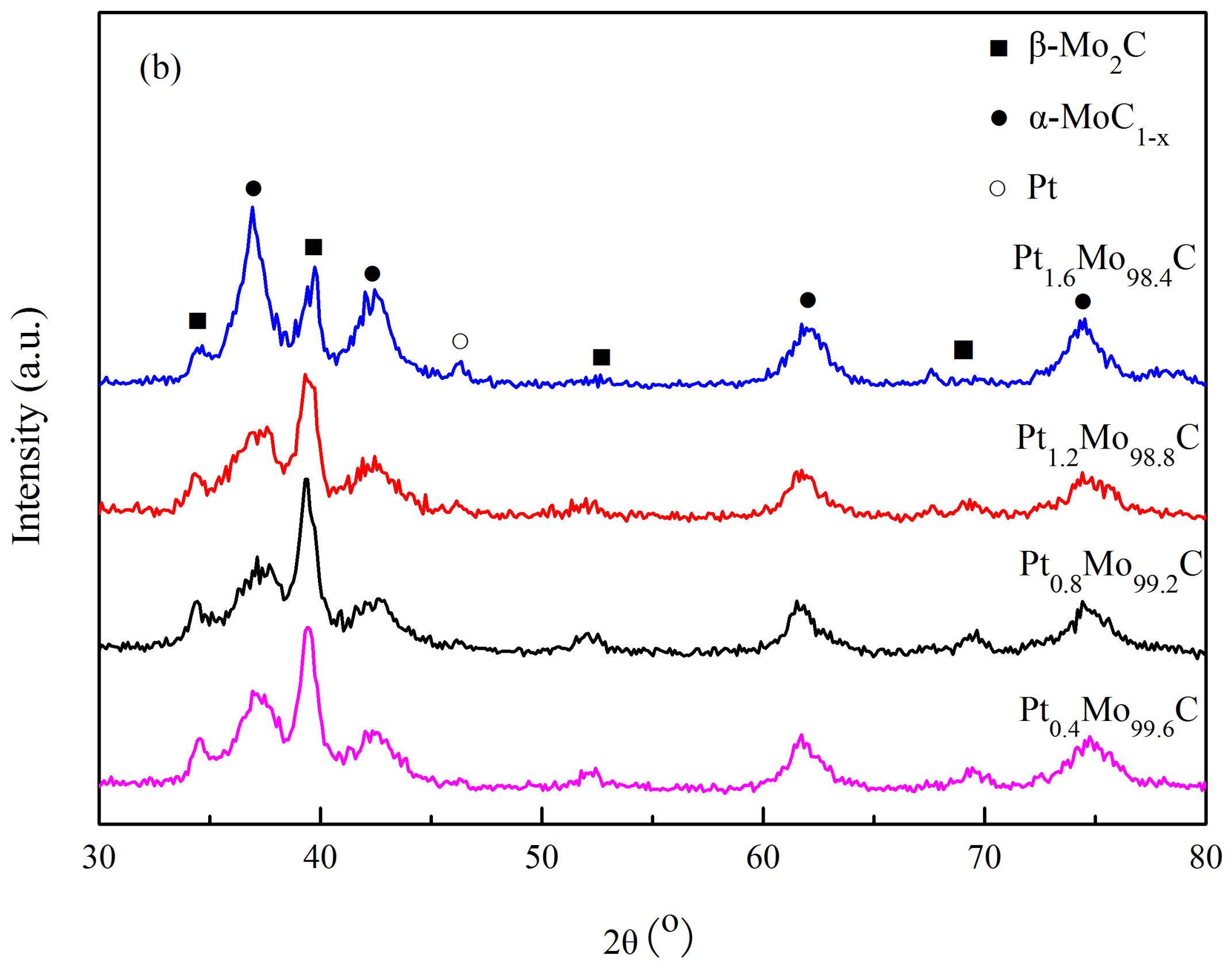




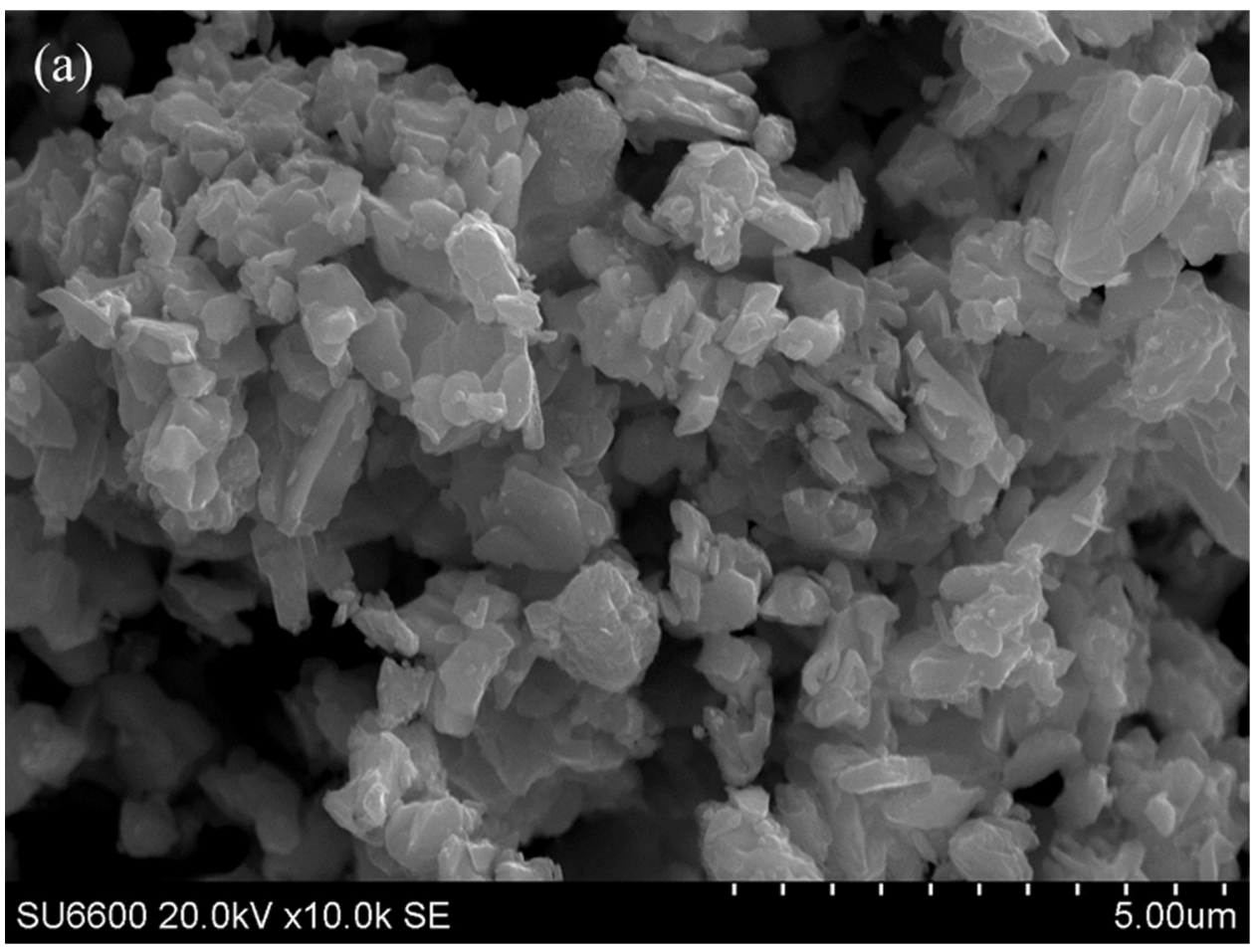




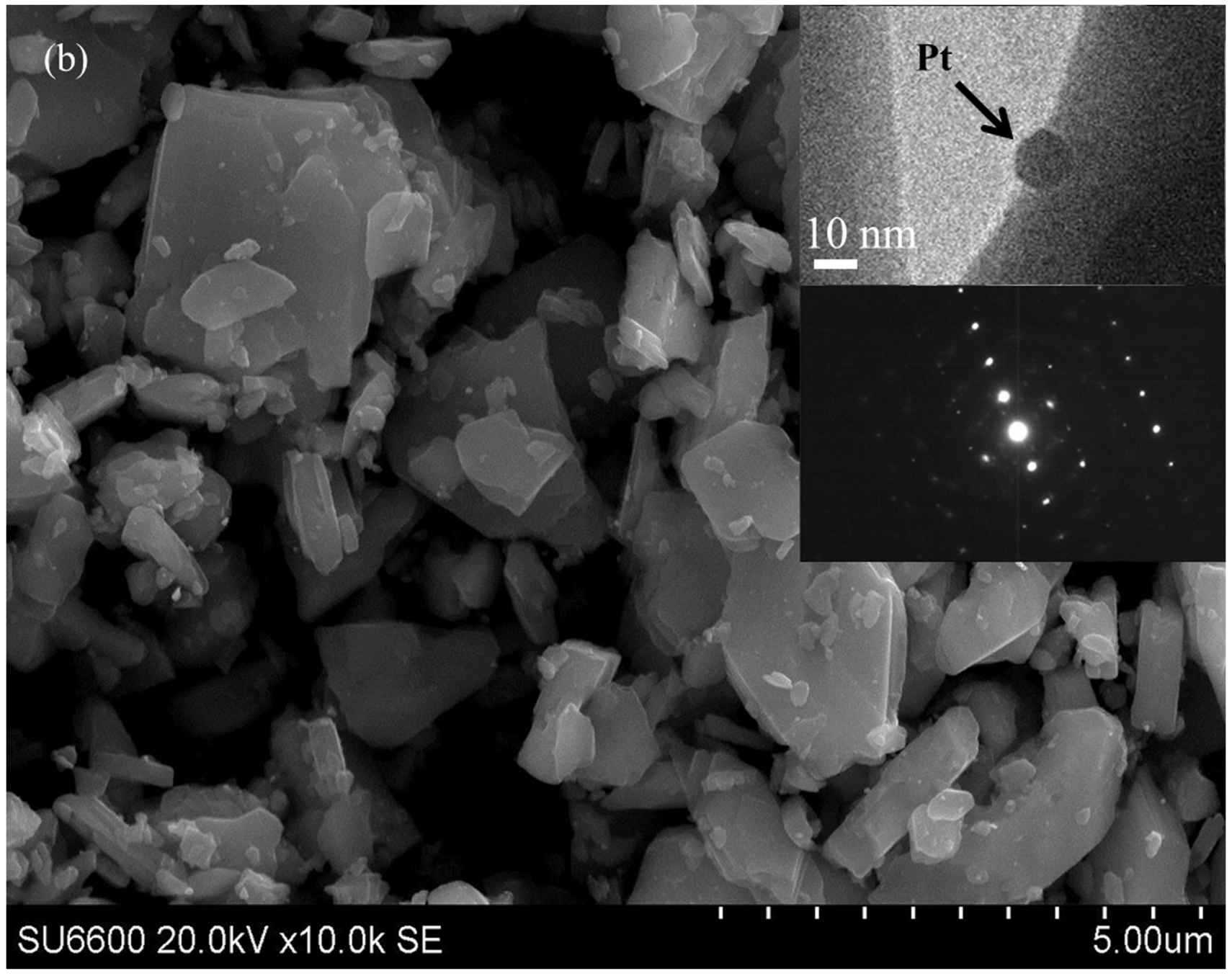




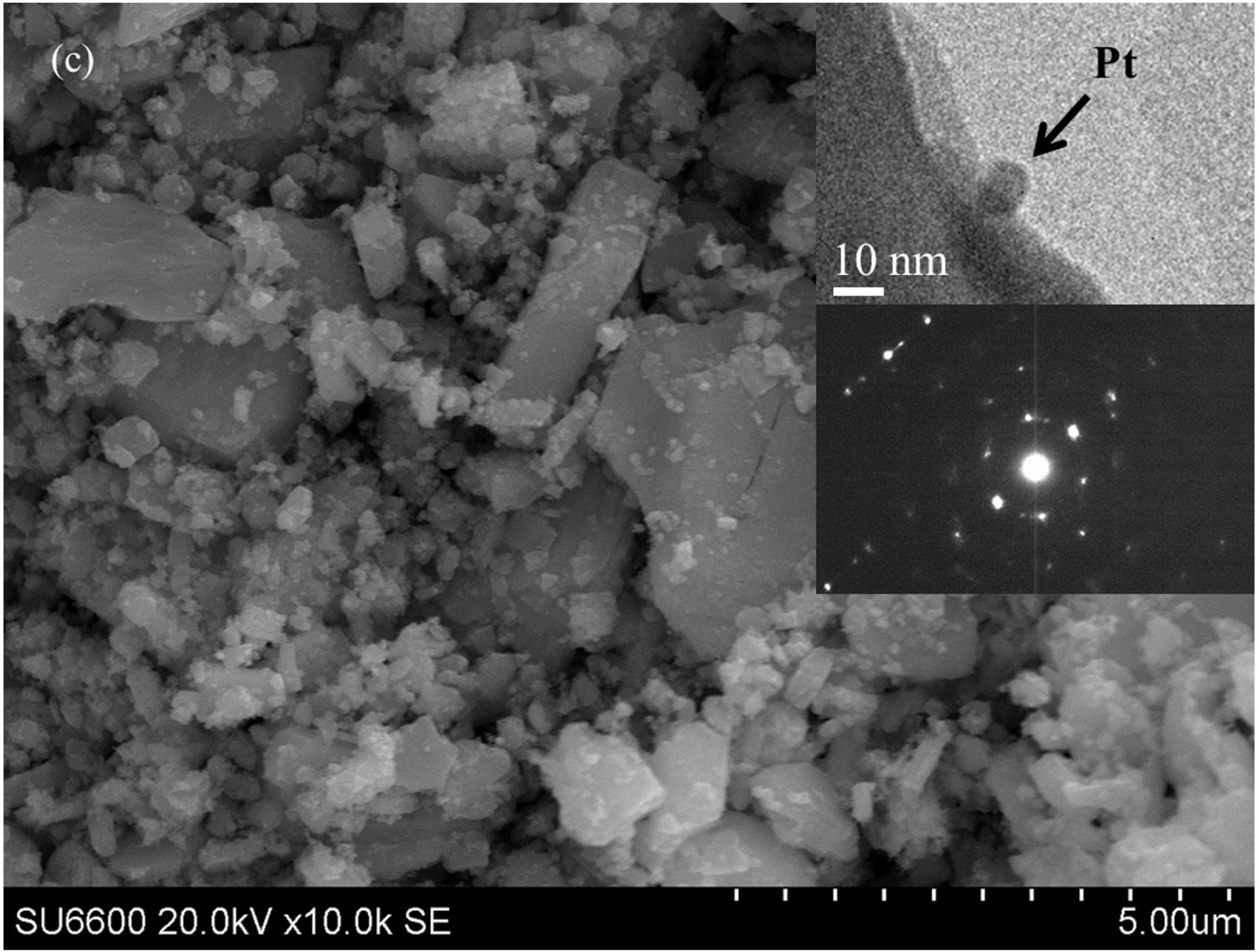




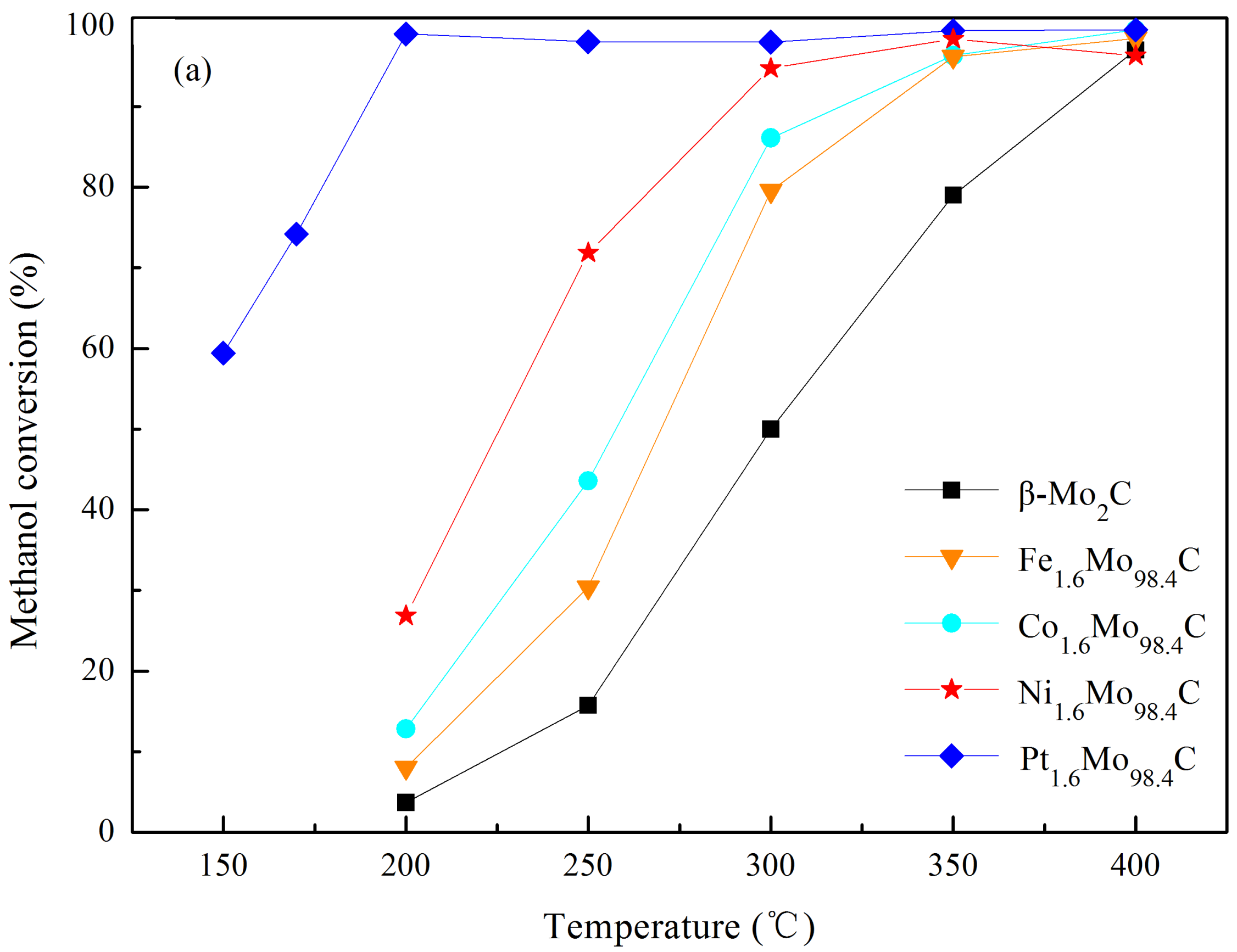




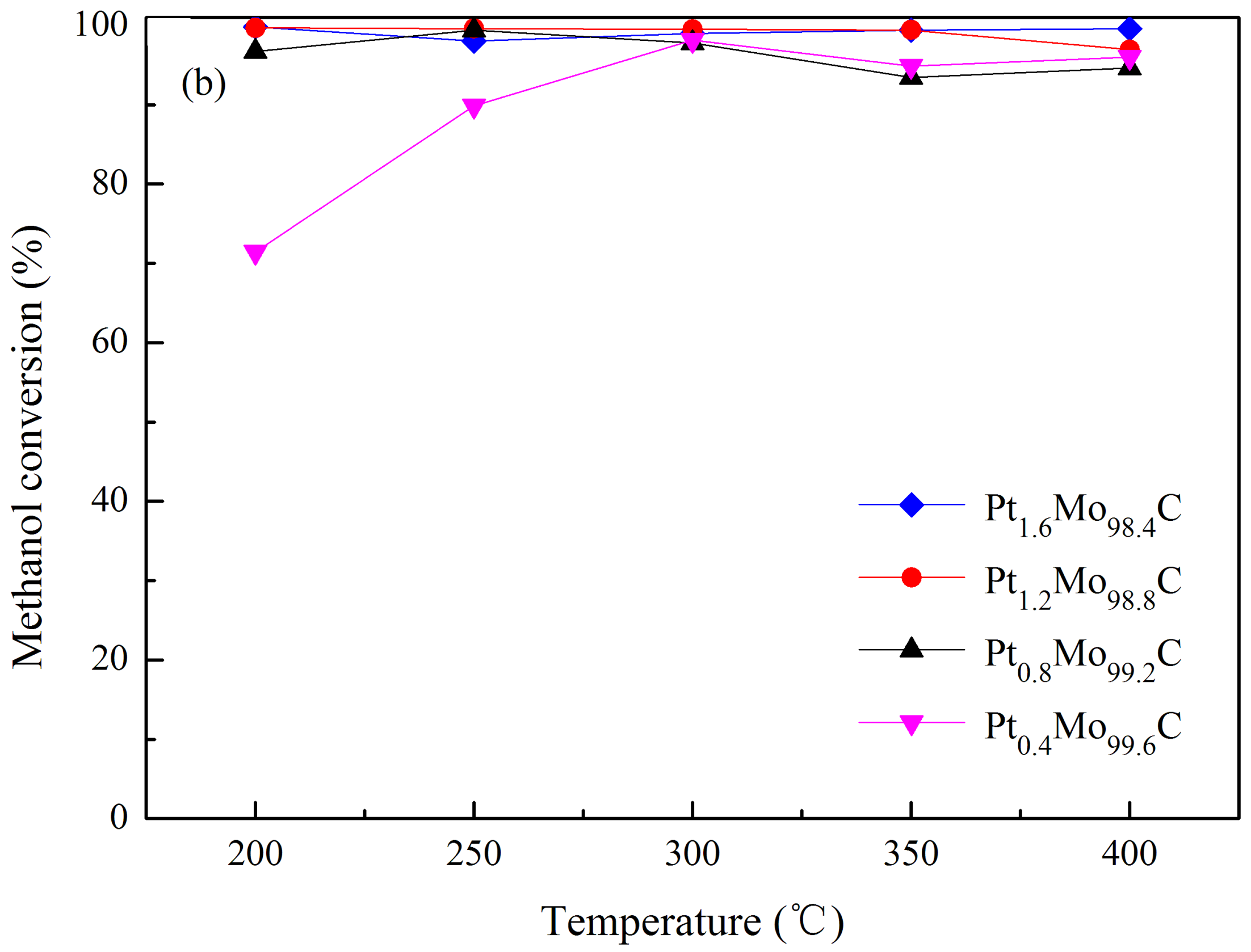




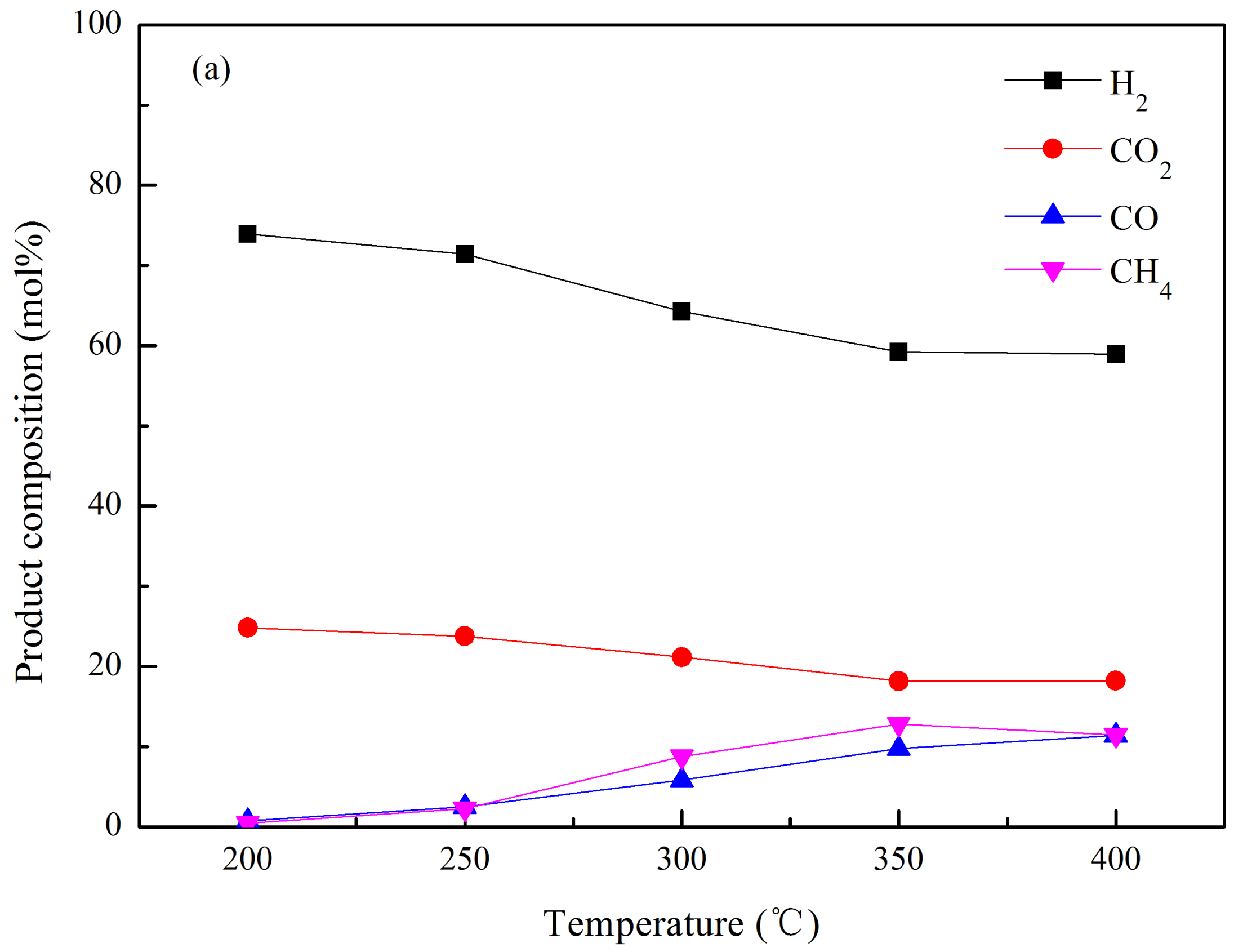




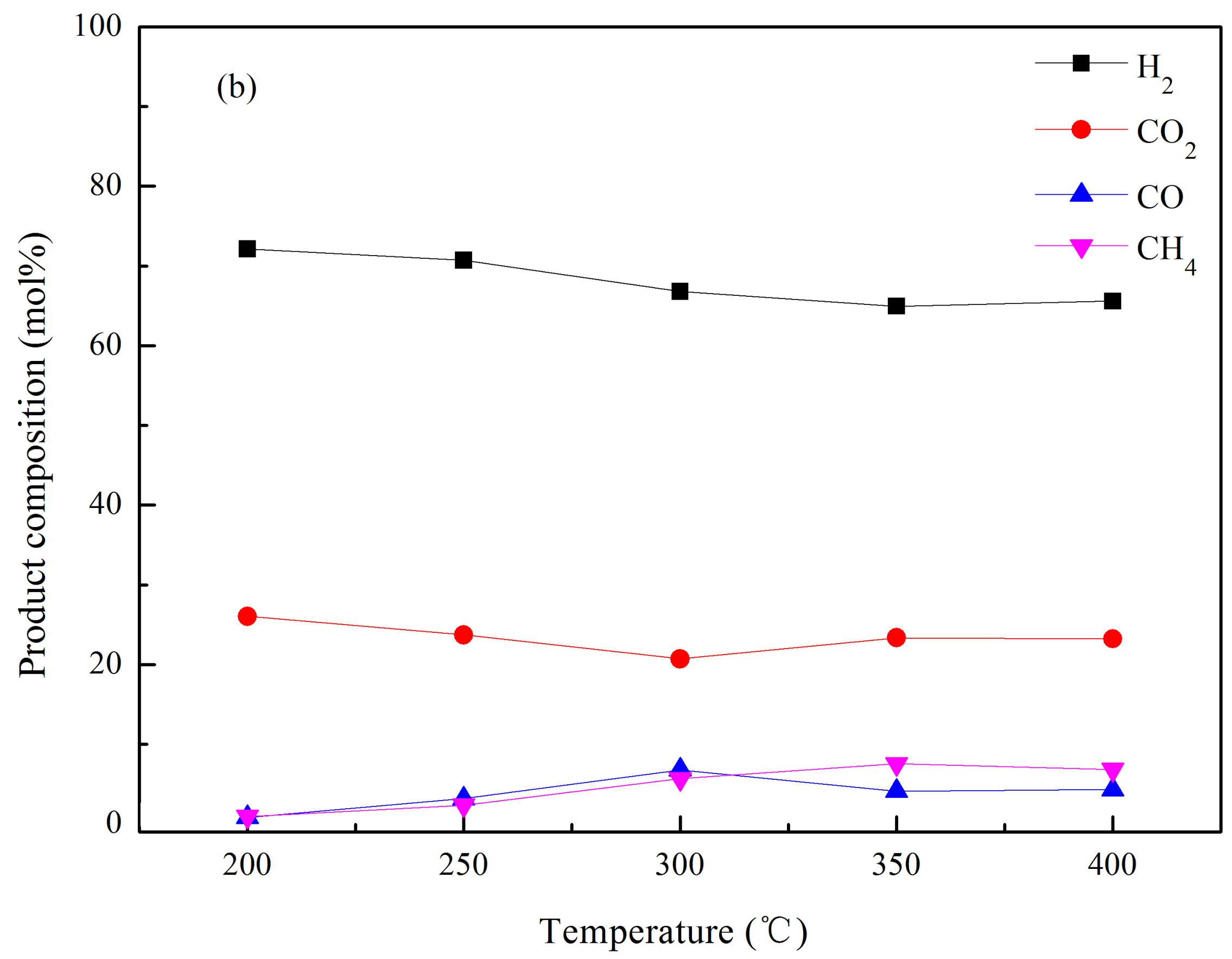




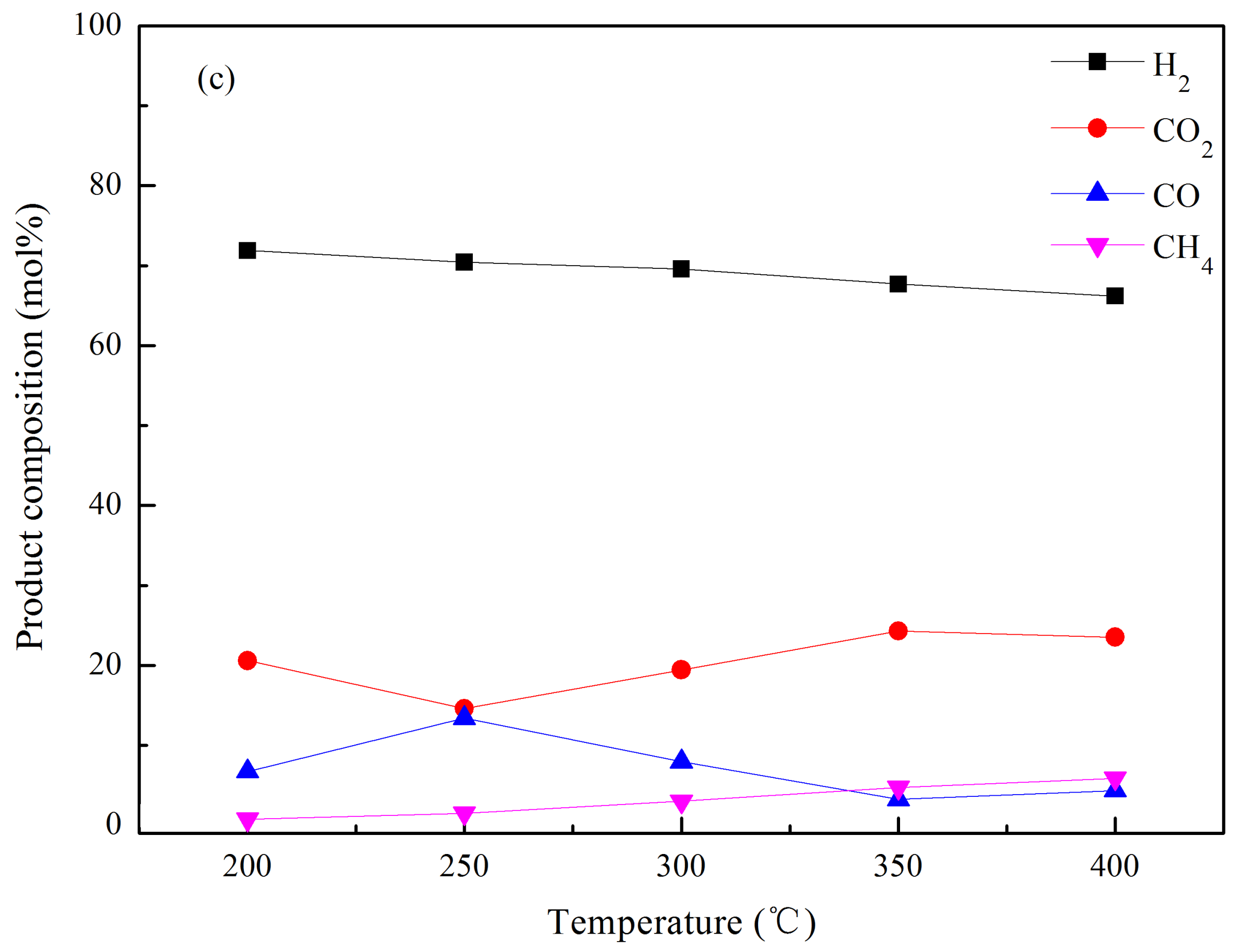




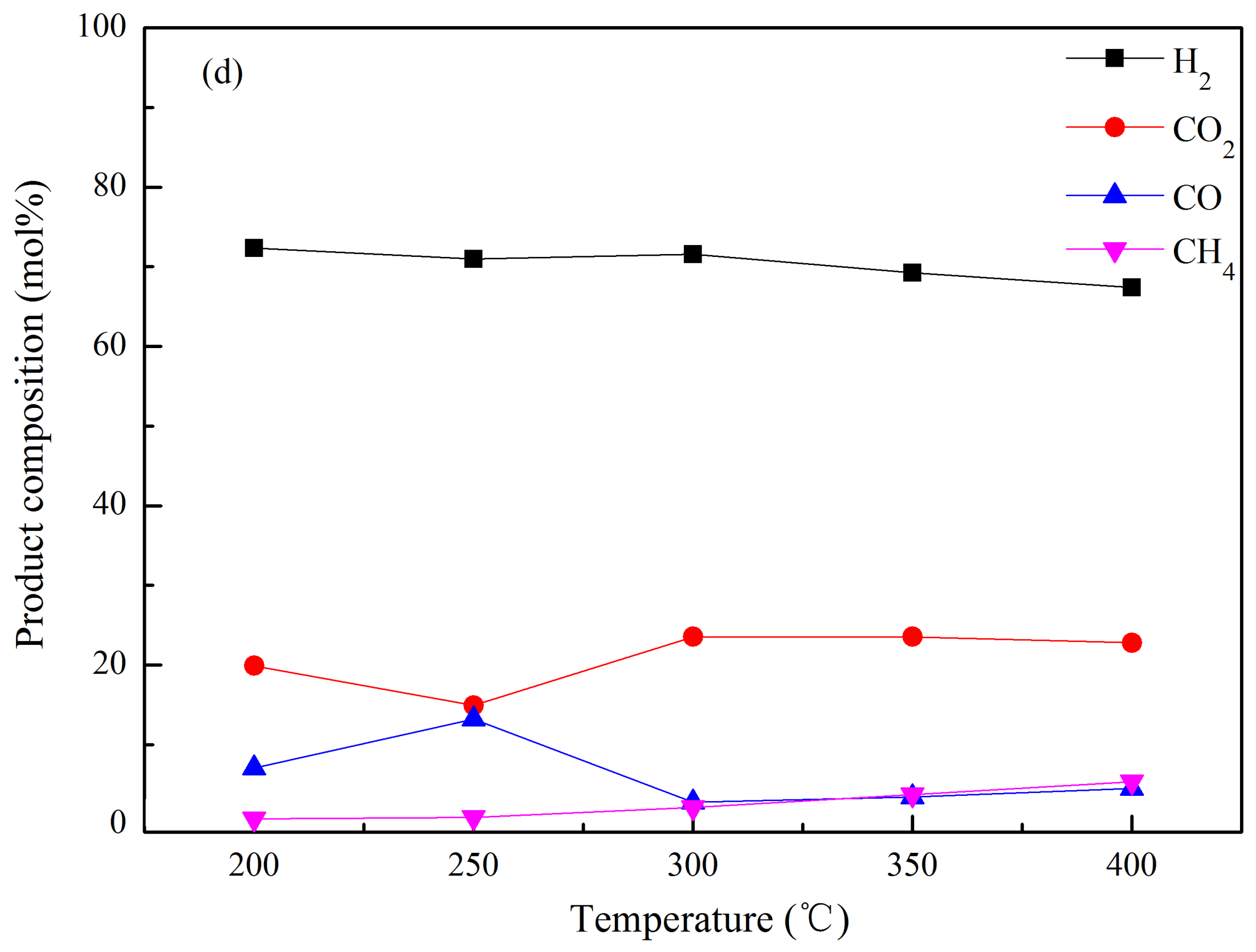




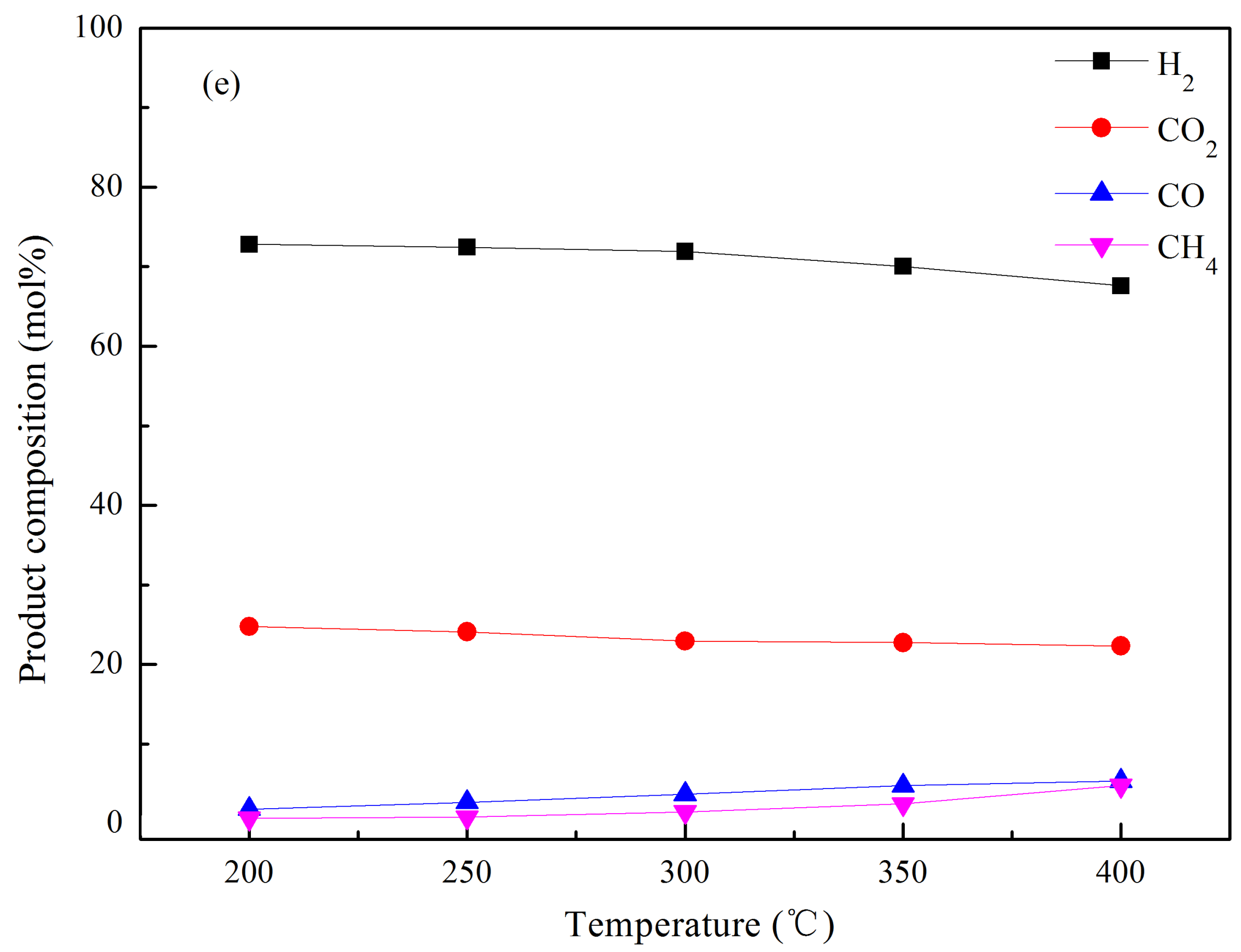




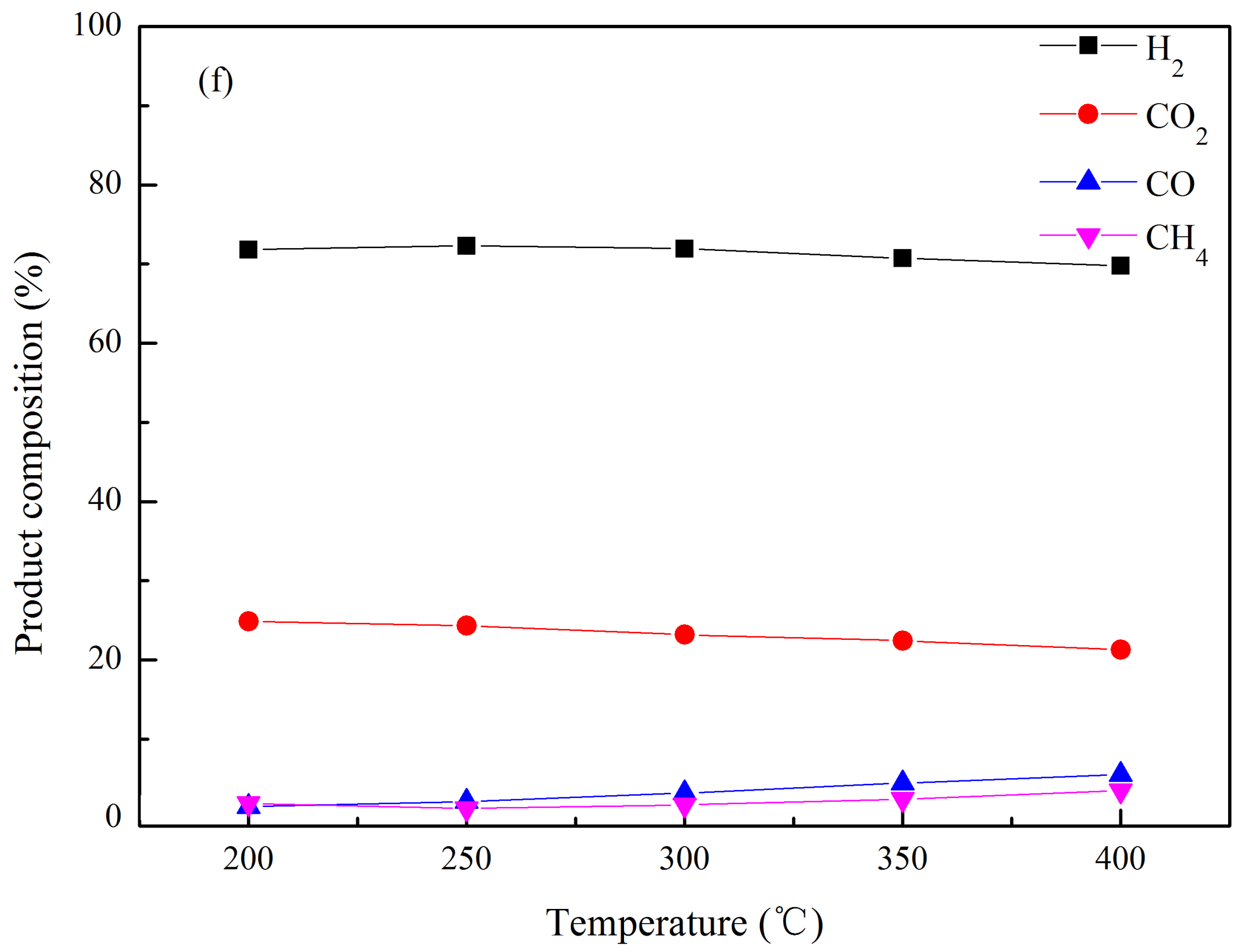


Figure 5

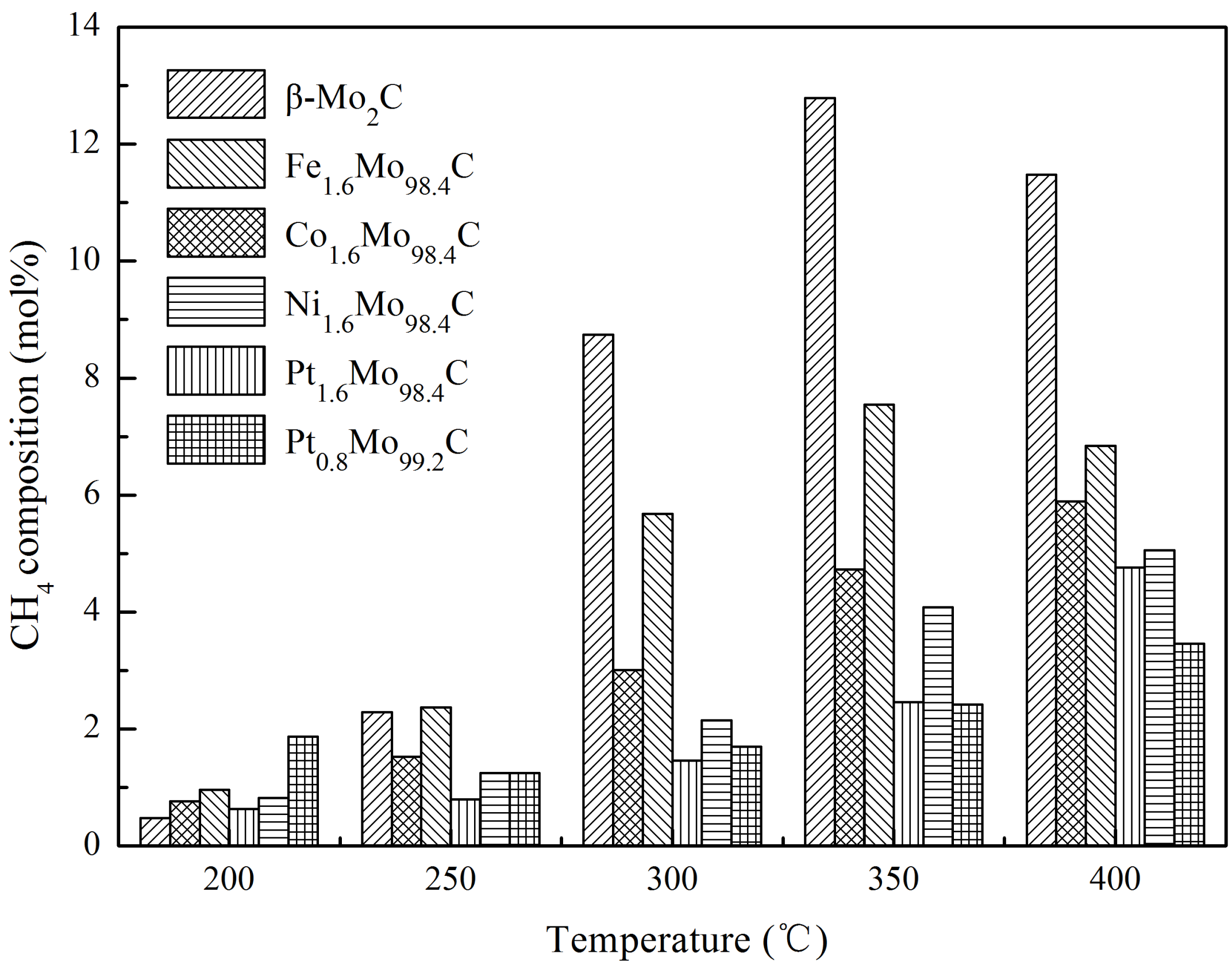




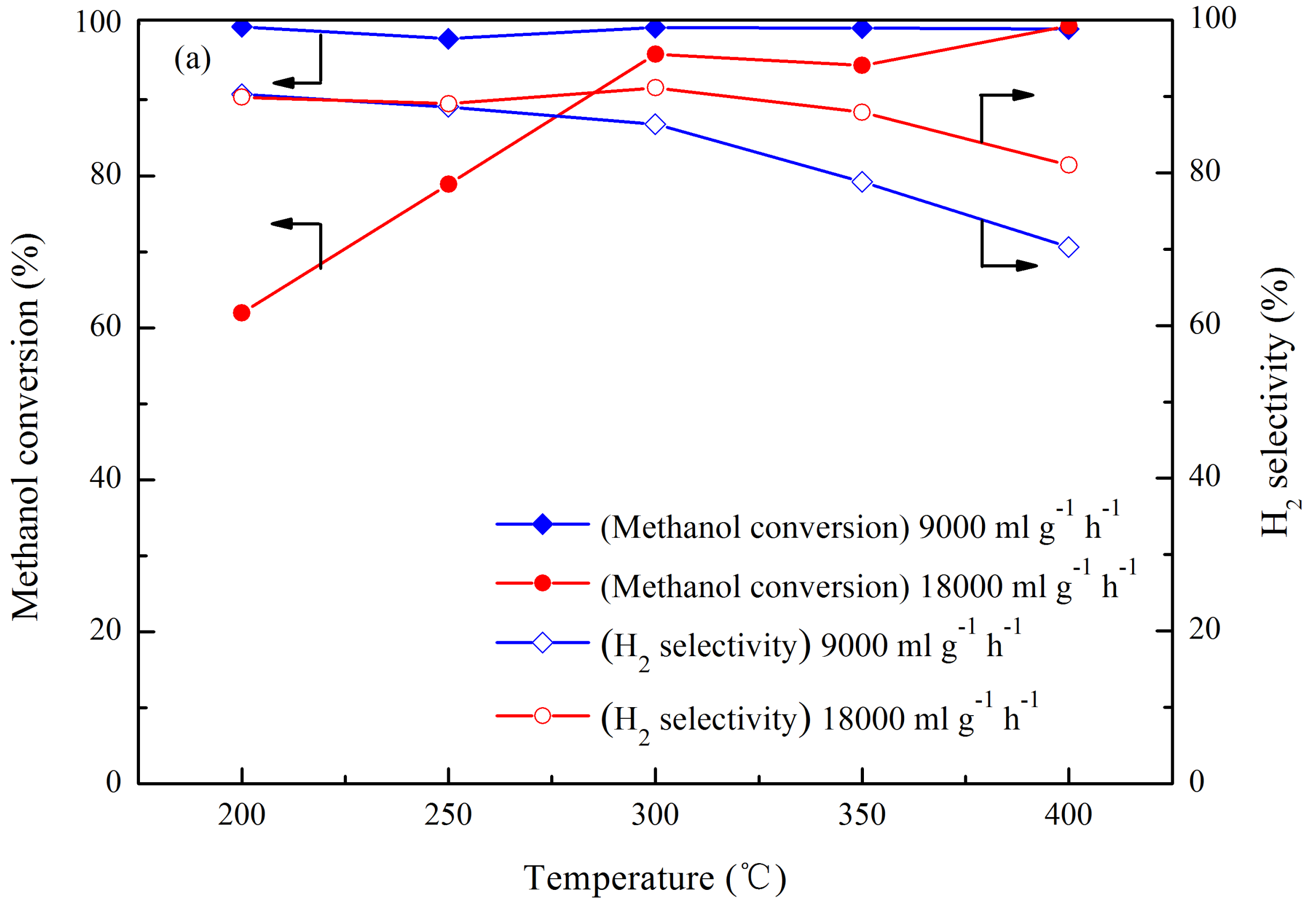




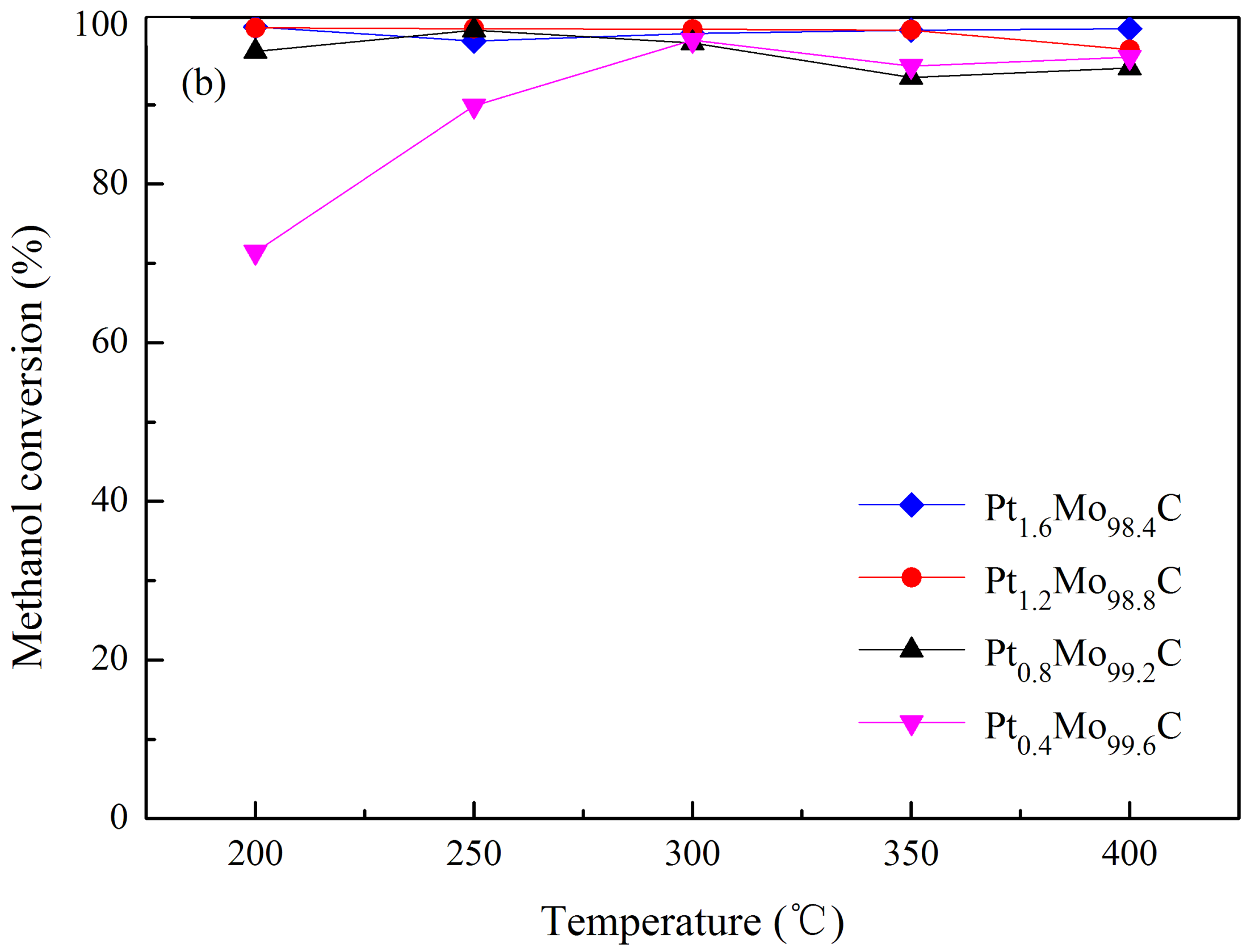




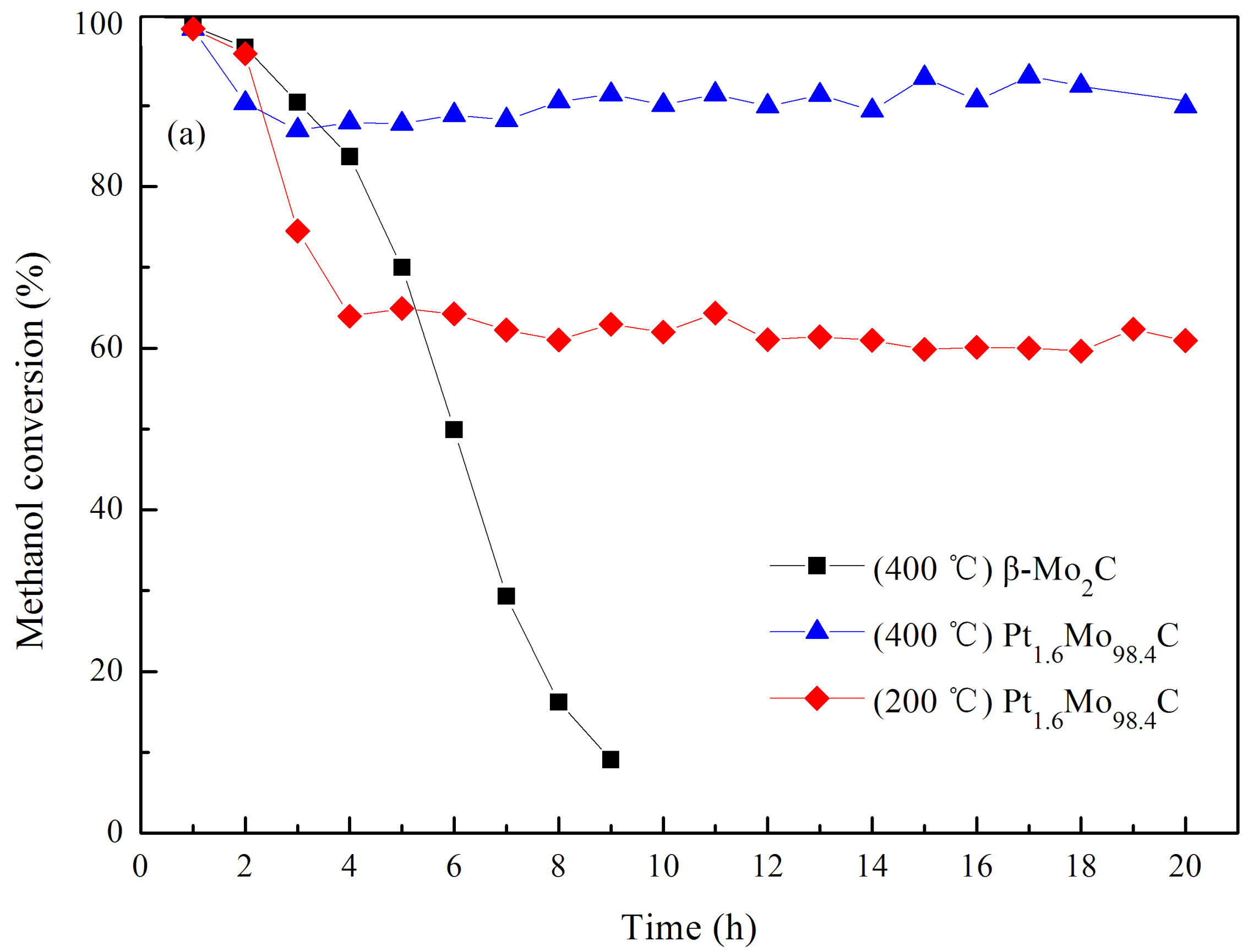




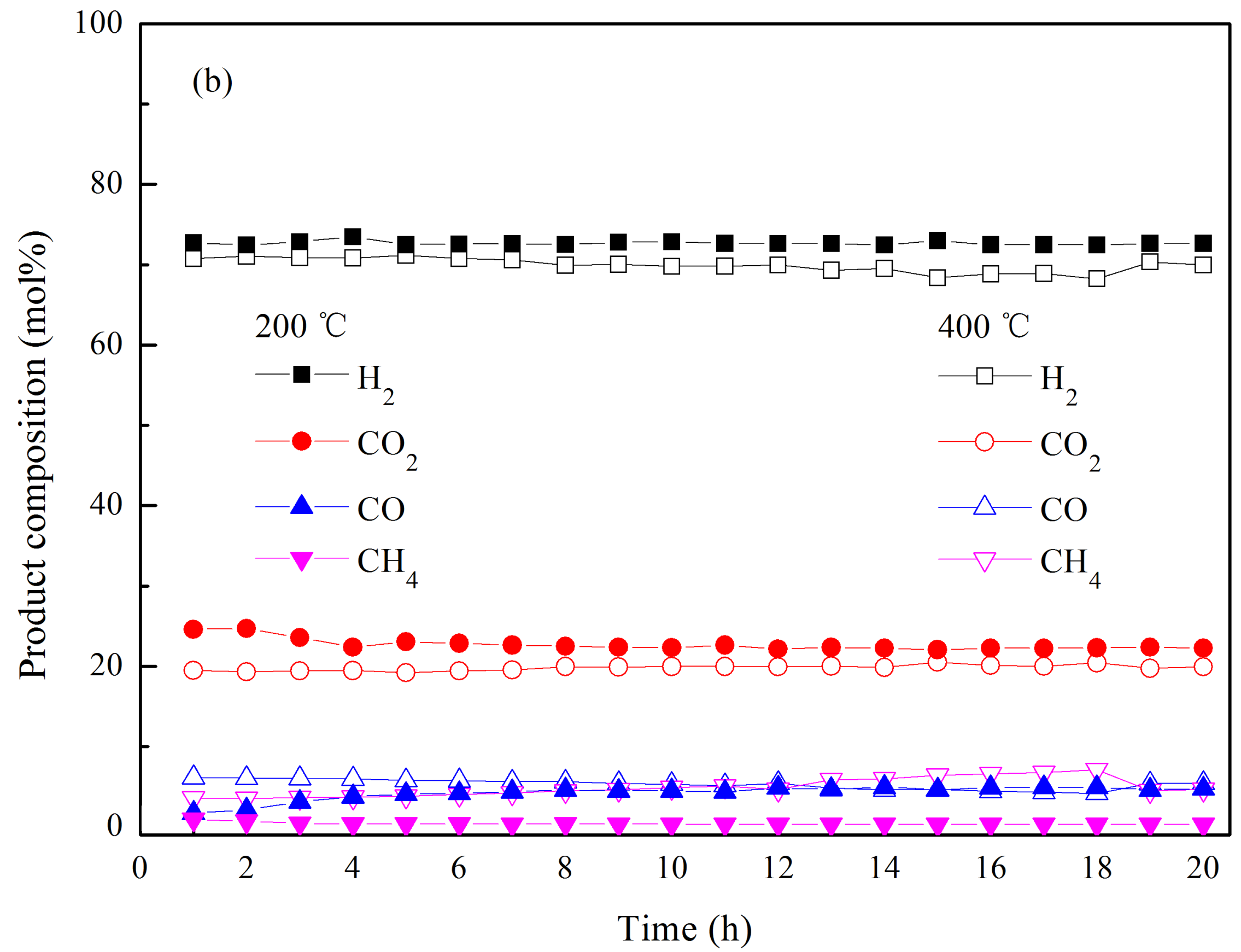




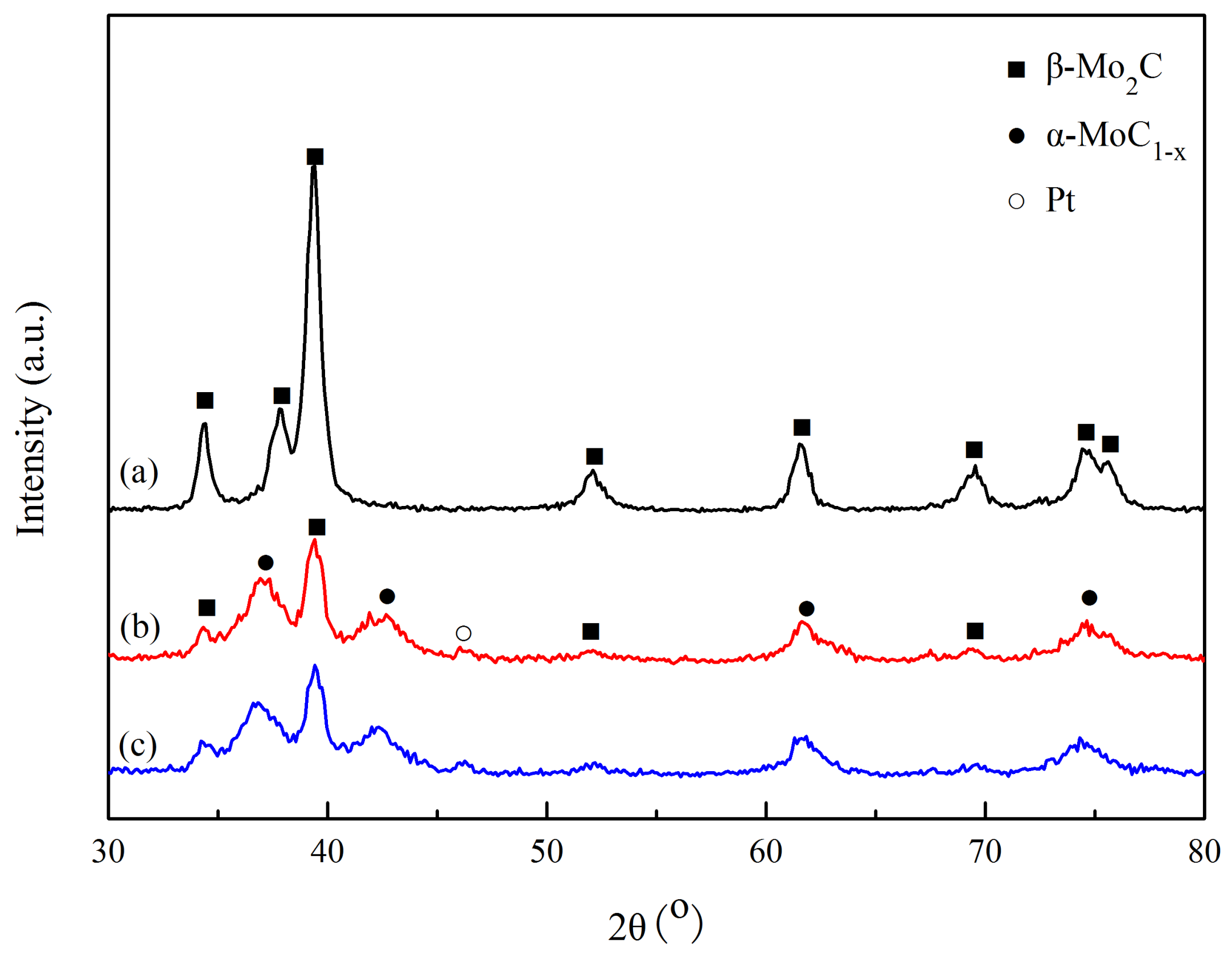



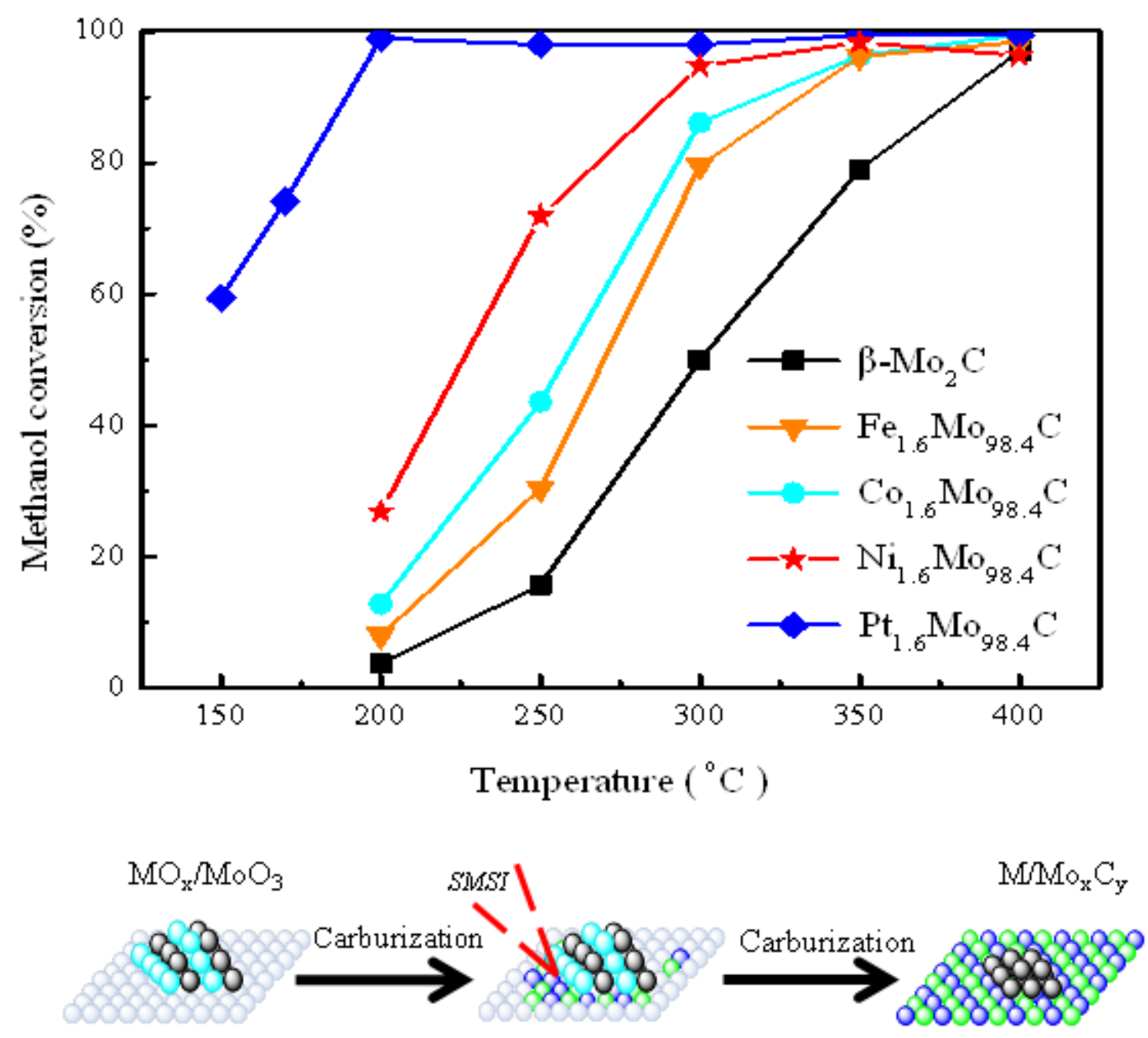